\title{
Espiritualidade(s) na corte (Portugal, c. 1450-C. 1520): que leituras, que sentidos?
}

Spirituality (ies) in the Court (Portugal, c. 1450-C.1520):
interpretations and meanings

\section{Maria DE LURDES RosA}

FCSH; IEM/ FCSH; CEHR-UCP

Universidade Nova de Lisboa

missi@oniduo.pt

\begin{abstract}
The article studies the spirituality of the late-medieval Portuguese court, first of all, as a historiographical problem, and then to propose specific readings of the historical materials. It begins with a reflection on key concepts: spirituality, religiosity, devotion; it then proceeds to analyze the «narratives of modernization» of Western history, focusing on the phenomenon of the court and its religiosity. In the second part, some characteristics of the spirituality (ies) in the Portuguese court will be presented, with a central focus on the lay courtiers: the extension of the idea of «court spirituality»; the figure of the king as its nucleus; finally, the ways those courtiers found to perform, for their own benefit and autonomously, the central operation of the «ecclesia» - to spiritualize the matter, thus creating a specific social circulation of charity.
\end{abstract}

Keywords: Late medieval Portuguese court; spirituality; religiosity; devotion; anthropological history.
Resumen: El artículo estudia la espiritualidad de la corte portuguesa tardo-medieval, en primer lugar, como problema historiográfico, para después proponer líneas de lectura de los materiales históricos. Empieza con una reflexión sobre los conceptos claves: espiritualidad, religiosidad, devoción; para pasar luego a las «narrativas de modernización» de la historia occidental en lo que toca al fenómeno de la corte y su religiosidad. En su segunda parte, presenta algunas características de la/s espiritualidad/es de la corte portuguesa, centrándose en los cortesanos laicos: el alargamiento de la idea de «espiritualidad de corte», la figura del rey como núcleo de la misma y, en fin, las fórmulas halladas para realizar, en provecho de esos y de forma autónoma, la operación central de «ecclesia» - espiritualizar lo material, creando una específica circulación social de la caridad.

Palabras clave: Corte portuguesa tardo-medieval; espiritualidad; religiosidad; devoción; historia antropológica 
Entre as muitas anedotas e historietas relativas à corte portuguesa de finais do século XV - meados do século XVI, que chegaram até nós recolhidas em compilações várias, uma das mais impressionantes é a história do criado do segundo Conde de Portalegre, João da Silva de Meneses ${ }^{1}$.

O dito criado, homem de grande bravura, aceita realizar uma proeza que fora considerada, em jantar de senhores, o gesto da máxima temeridade, cuja realização conferiria o lugar de mais corajoso da Casa: ir cortar um pedaço de camisa de enforcado, à noite, no Campo da Forca, em Lisboa. Ao fazê-lo, embarca numa extraordinária aventura, cujo relato nos é transmitido com a maior naturalidade e total ausência crítica face aos fenómenos sobrenaturais relatados. Para regressar mais depressa a casa, depois de cortada a alva do enforcado, o criado monta numa mula que encontra no local, e que não consegue ver bem devido à penumbra. A montada lança-se numa vertiginosa corrida pelos ares, e o criado empenha todas as forças em não cair; quando amanhece, vê que está numa cidade estrangeira, cheia de gente. Interrogando os passantes, fica a saber que é Roma; com o sangue-frio que o caracteriza, decide ir visitar o Cardeal, irmão do Conde, encontrando a morada com o auxílio dos romanos. O prelado, surpreendido mas satisfeito com a visita, escuta a narrativa do homem sobre o meio de transporte e o lapso de tempo, e aconselha-o a não voltar do mesmo modo; quando o criado recusa, limita-se a dar-lhe de comer enquanto escreve uma carta para o irmão, satisfeito pela presença do inesperado portador. $\mathrm{O}$ criado regressa no animal voador, chegando a Lisboa à noite. A mula demoníaca, que se vê durante o dia ser só «osso», desparece, e o criado vai narrar a sua proeza ao conde e aos outros membros da Casa, que todo o dia se tinham interrogado sobre o seu destino. O conde, ao princípio julgando estar perante um gozo, muda de opinião ao receber a carta do irmão. Depois de a ler, interroga o criado sobre a estranha viagem, a que a carta não parece aludir. Em bom senhor, dá a recompensa prometida, mas de seguida repreende e despede o homem. Não por questionar a história, mas apenas porque, tendo o criado sido enganado uma vez pelo demónio sem saber, se aliara depois a este em consciência, para voltar a Lisboa de forma expedita.

1 Em Anedotas Portuguesas e memorias biográficas da corte quinhentista, ed. C. C. LUND, Coimbra, 1980, pp. 194-197. O episódio não está datado, mas reporta-se a um momento posterior a 1540 e até 1551, sem que muito mais possamos saber (entre a fuga do Cardeal para Roma, Ana Isabel Buescu, D. Miguel da Silva e a Coroa portuguesa: diplomacia e conflito, in Rui MACÁRIO (coord.), D. Miguel da Silva - A Obra ao Tempo, Viseu, 2014, pp. 15-49) e a morte do Conde, antes do irmão (Anselmo Braamcamp FreIRE, Brasões da Sala de Sintra. Lisboa, 1973, vol. 3, p. 367). 
A história tem por base motivos muito antigos e bastante difundidos - a disputa pela melhor prova de coragem, a imprudência de brincar com os mortos - em especial os enforcados -, as montadas demoníacas que atravessam longas distâncias em pouco tempo, a carta como testemunho da estadia, o castigo final do criado, a própria cidade de Roma como destino e até os ambientes ligados a cortes, em que decorre ${ }^{2}$. Os contornos de realismo lhe são conferidos é que merecem interrogação. Desde logo, os protagonistas - um devoto Conde e um ilustre Cardeal, irmãos, entre cujos tios paternos se encontram, ainda, dois personagens maiores da vida religiosa recente, os irmãos Beatriz e João da Silva de Meneses $^{3}$. É particularmente intrigante o facto de o Cardeal, D. Miguel da Silva, de famosa formação humanística, paradigma do cortesão, se ter tornado o solícito anfitrião do criado montado na mula demoníaca. A sua reacção, bem como a do Conde, depois de estarem ao corrente da história, deixam também perplexidade, pois aceitam pacificamente que o criado tenha feito a viagem do modo que relata, em tal meio de transporte e lapso de tempo, e, até, decidem beneficiar da oportunidade, para trocar correspondência. Como explicar a origem deste episódio, e a sua presença num repertório de história relativas à corte, de origem coeva? ${ }^{4}$

Não cremos, desde logo, que tenha sido elaborada em qualquer contexto de perseguição régia ao Cardeal, mesmo se a sua estadia em Roma tinha este pano de fundo. Tal não tem grande sentido, tanto pelo carácter pícaro e mesmo algo disparatado da história, como pelo facto de nem o Cardeal nem o Conde poderem ser acusados de pouco mais do que credulidade; pelo contrário, um tenta inculcar prudência no criado, e o outro dispensa os seus serviços. Seria uma fraca forma de diabolizar os esforços do Cardeal e da sua família para iludirem a proibição régia da troca de correspondência. A hipótese alternativa de se tratar de uma plasmação de motivos antigos, alheios aos contornos históricos concretos, em função da notoriedade dos personagens em causa, é também forçada, dados os pormenores e o realismo de toda a narrativa - mesmo se fantástica. De resto, há múltiplos relatos deste tipo na mesma compilação, e é precisamente a forma anódina como são contados, e a naturalidade com os personagens - todos bem reais e identificados - que lhes confere a verosimilhança de terem circulado como reais, na época.

Se é um tanto posterior ao período central do nosso estudo, a historieta envolve um núcleo de pessoas que naquele viveram, e a que a historiografia tem

2 Como se verificará pela consulta dos motivos em Stith THOMPSON (ed. revista e alargada), Motif -index of folk-literature, Copenhaga, 1955-1958.

3 Sobre a devoção do conde e os parentescos, Ana Isabel Buescu, D. Miguel da Silva ..., pp. 16-19.

4 Sobre o contexto, autoria, datação, cfr. C. C. Lund, Anedotas Portuguesas..., pp. 17-26. 
conferido características de especificas religiosidades de corte, que nos interessa aqui abordar: devoção aos franciscanos reformados, humanismo, ligação familiar a reformadores eclesiásticos, que agem e ganham fama de «santos vivos» em duas relevantíssimas cortes, penetradas pela modernidade, a dos Reis Católicos e a de Roma. Paradoxos e ambiguidades deste tipo têm merecido pouca atenção por parte dos historiadores da corte portuguesa tardo-medieval e quinhentista. $\mathrm{Na}$ verdade, a história da mula voadora encarada com naturalidade, e usada como meio de correio por duas figuras como as implicadas, não é fácil de interpretar recorrendo à investigação histórica tradicional, que visa antes de mais reconstruir ambientes e personagens. Forçoso é passarmos, então, para um segundo nível, ou se quisermos, uma questão de fundo, que tem inquietado os «historiadores antropólogos» medievalistas: como encarar estas narrativas e as sociedades que as produzem e nelas acreditam? Como «levá-las a sério»? ${ }^{5}$. Assumindo as dificuldades que estes relatos e práticas, e a forma natural como foram aceites, têm colocado à interpretação histórica, os medievalistas ligados à antropologia histórica trabalharam para desenvolver interpretações não anacrónicas, a partir da aceitação de uma racionalidade própria e claras funções sociais aos mesmos. O que aqui tentaremos - mais do que uma síntese, uma proposta de leitura das «espiritualidade(s) na corte» tardo-medieval portuguesa - deve muito a esta historiografia. É antes de mais imperativo proceder à revisão dos conceitos, bem como interrogar as visões historiográficas de fundo, usadas muitas vezes sem lhe prestarmos demasiada atenção, para assentar e conferir coesão aos novos achados: no contexto em análise, há, nas leituras correntes, demasiadas «junções perigosas» entre elementos como a corte, a «modernidade», ou «medievalidade», a religião/ espiritualidade/ devoção, Reforma e Reforma Católica, para que se possa deixar de lhes prestar atenção.

No presente artigo, procuraremos realizar um itinerário abrangente sobre o tema. Reflectiremos brevemente, de início, sobre a adequação a fazer a alguns conceitos-chave, para o seu uso em análise de contextos tardo-medievais e altomodernos: espiritualidade, religiosidade, devoção; examinaremos, depois, a questão das «narrativas de modernização» da história ocidental, aqui sobretudo no

5 Para um balanço sobre a Antropologia Histórica aplicada ao estudo da Idade Média, cfr Faire l'anthropologie bistorique du Moyen Âge. L'Atelier du Centre de recherches historiques. $\mathrm{n}^{\circ}$ 7, [n.p.], 2010. Disponível em: <http://acrh.revues.org/index1911.html>; e Étienne ANHEIM, L'bistorien au pays des merveilles?, in L'Homme [En ligne], 203-204 I 2012. Disponível em <http://lhomme. revues.org/23239>. Para a medievalística de língua inglesa, em especial quanto à história religiosa, cfr. John ARNOLD, Belief and unbelief in medieval Europe, Londres, 2010, pp. 7 ss. 
que toca ao fenómeno da corte e sua religiosidade. Na segunda parte do artigo, apresentaremos algumas características $\mathrm{da}(\mathrm{s})$ espiritualidade(s) na corte portuguesa de finais da Idade Média (c. 1450-c. 1520), tendo como foco central os cortesãos leigos. Entre muitos aspectos possíveis, foi obrigatório seleccionar os que considerámos centrais e, ainda, susceptíveis de trazer mais novidades, se relidos segundo as perspectivas historiográficas propostas. Assim, principiaremos por argumentar que um alargamento da ideia de «espiritualidade de corte», como sugere a historiografia antes apresentada, traz à consideração diversos campos referenciais da mesma, que coexistiram e competiram entre si, de forma positiva por vezes. Avançaremos de seguida para o que consideramos ser o núcleo da espiritualidade na corte - a figura do rei, nas relações que estabelece com o campo religioso específico da corte, do reino, e da Igreja. Resta para uma terceira parte, subordinada à ideia de mecanismos sociais de recepcionar e gerir a mensagem religiosa, a análise de um campo de acção onde é especialmente evidente a capacidade dos leigos para uma recriação própria da espiritualidade: as formas encontradas para realizar, em proveito próprio e de forma autónoma, a operação central da «ecclesia», ou seja espiritualizar a matéria, criando uma específica circulação social da caridade, motor do sistema da Cristandade.

\section{RELIGIÃO, ESPIRITUALIDADE, DEVOÇÃO}

Sem pretensões de exaustividade num campo de estudos que tem gerado vasta bibliografia nas últimas décadas, concentrar-nos-emos na apresentação da adequação do conceito de religião pela antropologia histórica medievalistica francesa, cuja relevância é amplamente reconhecida. Em primeiro lugar, é importante lembrar que a revisão deste conceito se inscreve numa opção teórica global, que é o uso da antropologia para a interpretação do período medieval. Assim, a par do questionamento de «religião», e em função das sugestões analíticas de base antropológica, a «arte» foi reconsiderada como «imagens», o parentesco foi construído como objecto historiográfico e foram descobertas as suas fundamentais funções sociais nas sociedades históricas e, entre outros campos de estudo, o exercício do direito, as noções de guerra e a paz, vingança e honra, foram redescobertos numa pluralidade de formas ${ }^{6}$. É neste âmbito que

6 Jean-Claude Schmiтt, Anthropologie historique, in Bulletin du centre d'études médiévales d'Auxerre I BUCEMA [En ligne], Hors-série n ${ }^{\circ} 2$ | 2008. Disponível em <http://cem.revues.org/8862>. 
deve entender-se a recusa da aplicação de um conceito de religião oriundo do mundo contemporâneo:

(...) la notion même de «religion» est-elle justifiée quand l'historien s'applique à rendre compte des représentations et des pratiques rituelles, collectives et individuelles, ayant trait à la représentation du divin dans l'Europe médiévale ? (...) Mieux vaut donc, pour éviter toute confusion, employer d'autres mots et parler plutôt, comme les anthropologues, de systèmes symboliques - ou, d'une manière moins stricte, de «dimensions symboliques» - c'est-à-dire, de croyances, de mythes, de rites qui énervent l'ensemble des représentations et des pratique sociales $(. . .)^{7}$.

Com esta reconsideração da instância religiosa propriamente dita, o alargamento é imenso e com profundas consequências para a apreciação do fenómeno da religiosidade cortesã. Por exemplo, numerosos aspectos que tradicionalmente era vistos com carácter de bizarria, magia, ou superstição, e que agora alguma historiografia «mais modernizante» vem interpretar como «demonstrando a inserção da corte na sociedade "do seu tempo" »- onde, aí sim, imperaria uma baixa cultura de raiz popular, inculta-, podem ser considerados perfeitamente áulicos, e com um carácter fortíssimo de distinção social. Será o caso, entre outros, da relação religiosa da corte com as relíquias; ou dos «santos de corte» vistos como encarnando forças carismáticas de diversa origem; ou, ainda, os actos de beneficência encarados como formas de transformar a matéria em bens espirituais. E, sem querer transformar a corte tardo-medieval a golpes de arcaísmo (bem pobre operação para o uso da antropologia), as dimensões comunitárias da religião devem ser pelo menos consideradas tão importantes quanto as individualistas. A todos estes aspectos voltaremos no decorrer do texto.

Quanto à «espiritualidade», poder-se-ia pensar que uma consideração antropologizante da religião, dificultaria a compreensão do fenómeno. Na verdade, permite reconfigurá-lo, pela procura do sentido próprio à época. Impede-se por um lado a pietização, anacrónica, e, por outro, a intelectualização, tendenciosa. A primeira operação ocorre na historiografia eclesiástica oitocentista que, partindo das práticas «piedosas» da sua própria época, fortemente reparadoras e emocionais por reagirem aos «ataques» do laicismo e anticlericalismo, procurou conferir-lhes uma venerável antiguidade, ancorá-las na solidez e fé profunda dos

7 Jean-Claude SchmitT, Préface, in Le corps, les rites, les rêves, le temps. Essais d'anthropologie médiévale, Paris, 2001, pp. 5-28 (pp. 10-11) ; na mesma obra, cfr. Une bistoire religieuse du Moyen-Âge est-elle possible?, pp. 32-41. 
tempos medievais, perfeitamente «espirituais», superiores à materialidade crua que acabara por triunfar. A segunda tem pergaminhos mais antigos, no próprio pensamento eclesiástico, em especial o reformista. $\mathrm{Na}$ vida religiosa, teria existido desde sempre uma divisão entre a espiritualidade e a exteriorização, sendo a primeira mais nobre, porque «pura» e.. espiritual, e só ela permitindo alcançar a Deus. Se houve versões mais emocionais desta leitura (a teologia negativa, por exemplo), o fundo permanece o mesmo, assente na convicção da supremacia dos que realmente sabem, pensam e estudam, ou seja, os teólogos, opostos aos leigos, capazes de aceder apenas sensorialmente - logo, rudimentarmente - ao divino ${ }^{8}$. Facilmente se compreende como o uso desprecavido de um conceito com este tipo de camadas valorativas, pode ocultar vestígios já de si pouco perceptíveis - particularmente os dos leigos, numa organização fluida como a corte - e, logo, impedir análise da sobreposição de campos referenciais. É útil aqui relembrar, apesar das décadas com que conta já, a abordagem de um dos mais consagrados historiadores da espiritualidade medieval, André Vauchez, que nasceu precisamente do seu trabalho sobre os leigos:

Spiritualité, qu'est-ce à dire? (...) Le Moyen Age ne la pas connue [cette notion] et s'est contenté d'un distinction entre doctrina, c'est-à-dire la foi sous son aspect dogmatique et normatif, et disciplina, sa mise en pratique, en général dans le cadre d'une règle religieuse. Le mot spiritualitas que l'on rencontre parfois dans les textes philosophiques à partir du douzième siècle n'a pas de contenu spécifiquement religieux : il désigne la qualité de ce qui est spirituel, c'est-à-dire indépendant de la matière. En fait, la spiritualité est un concept moderne, utilisé depuis le dix-neuvième siècle.

(...) A côté de la spiritualité explicite des clercs et des religieux, formulée dans des écrits, il en existe à notre avis une autre, qui a laissé peu de traces dans les textes, mais dont nous constatons la réalité à travers d'autres modes d'expression : gestes, chants, représentations iconographiques, etc. Dans cette perspective, la spiritualité n'est plus envisagée comme un système codifiant les règles de la vie intérieure mais comme une relation entre certains aspects du mystère chrétien particulièrement mis en valeur à une époque donnée et des pratiques (rites, prières, dévotions), ellesmêmes privilégiées par rapport à d'autres pratiques possibles à l'intérieur de la vie chrétienne?.

8 Discussão deste panorama historiográfica em Maria de Lurdes RosA, Sagrado, devoções e religiosidade, in Bernardo Vasconcelos e SOUSA (coord), História da Vida Privada em Portugal, Lisboa, 2010, vol. I, pp. 376-401.

9 André VAUCHEZ, La spiritualité du moyen âge Occidental (VIIIe-XIIIe siècle), Paris, 1994, pp. 7-8. 
Vista sob esta perspectiva, a «espiritualidade de corte» não se reporta tanto ao que seria identificado como manifestações mais interiores ou clericalizadas de viver a religião, por parte de cortesãos piedosos; ou tão pouco ao conjunto de ideias e práticas que se aproximasse, pela sua completitude, profundidade ou coesão, da esfera eclesiástica. Os «cortesãos espirituais» talvez não tenham existido - pelo menos decerto não existiram tal como as crónicas monásticas os inventaram: em necessária oposição e mesmo em fuga, à mundanidade da corte, à espiritualidade aparente e vã que esta fomenta. E tão pouco como os viu diversa historiografia, ou por ler literalmente estas fontes, ou por visões anacrónicas do fenómeno religioso. Como tentaremos demonstrar, a recriação das mensagens religiosas foi intensa mas própria, indissociável dos quadros sociais próprios da sociedade leiga, e em meios mais cultos e com maior literacia, como a corte inglesa tardo medieval, deu a certa altura um lugar central à crítica exacerbada das propostas eclesiásticas para moldar a relação de cada um com a divindade ${ }^{10}$.

Um último conceito que tem vindo a ser retrabalhado com interessantes resultados, em especial pela historiografia inglesa, é o de «devoção», ou «práticas devocionais», para sublinhar o carácter dinâmico daquela atitude. Estas reportam-se a um campo vasto de acções a meio caminho entre a religião e a vida social, que aliam uma postura religiosa afectiva a um sentimento de pertença a algo ou alguém divino, sendo-se protegido pelo objecto de devoção. As práticas devocionais incluem as orações, as leituras de textos religiosos, os diversos usos dos objectos sacros, as manifestações de caridade, as vivências específicas da liturgia, nomeadamente para celebração e intercessão dos parentes e amigos. A performatividade, a acção, a expectativa de um resultado social, e o carácter misto que isto imprime aos modelos eclesiásticos, são aspectos aqui extremamente importantes. Exemplos claros da abertura de horizontes que tal permite é o uso de conceitos como «literacia religiosa» ou «cultura litúrgica», para substituir o de «leituras religiosas» e a «liturgia» com a tonalidade «piedosa» (à século XIX) da historiografia eclesiástica, ou com a visão de «mais alta cultura» da História da cultura e da literatura do «Renascimento». Permite aproximar as práticas em estudo a dinâmicas de inserção social «pouco religiosas», no sentido estrito do termo - distinção social, mecenato, securização, afirmação familiar ou pessoal - mas que no período em estudo se efectivavam em «ambiente religioso». A historiografia inglesa dita «revisionista»- em função da releitura que tem feito às origens do protestantismo

10 Katherine LiTTLE, Confession and resistance. Defining the self in late medieval England, Notre Dame, 2006. 
inglês, que inclui uma crítica aos seculares usos políticos deste-, lê as devoções nesta chave e encontra através delas um mundo religioso vibrante tardo-medieval, mas muito diverso das leituras dos «leigos piedosos e cultos» ${ }^{11}$. Nele, a magia e a manipulação das entidades sacras, coexistem com formas próprias de piedade profunda, com a leitura de «autores espirituais» e com a intervenção na reforma da igreja. Segue, porém, normas e ideias próprias, que valorizam aspectos como o poder, a distinção social, a vivência comunitária, a continuidade e reforço da estruturação pelo parentesco de sangue, a religiosidade doméstica.

\section{A MODERNIDADE DA ESPIRITUALIDADE DE CORTE}

Ainda que brevemente, consideramos importante abordar uma última questão, de ainda mais vasto escopo que a revisão e adequação de conceitos. Referimo-nos à crítica historiográfica das «narrativas de modernização» da história medieval, que têm surgido no âmbito da influência do pensamento pós-moderno na História ${ }^{12}$. Embora elas abarquem diversos quadrantes da sociedade, referiremos aqui apenas o que mais directamente toca ao fenómeno da religiosidade/ espiritualidade de corte.

A corte foi encarada nas ciências sociais, desde Elias, como um dos mais importantes lugares de desenvolvimento de comportamentos associados à modernização da sociedade: a etiqueta, o controlo das pulsões, a codificação da violência $^{13}$. Por outro lado, em múltiplas leituras historiográficas, um outro vector da modernidade social, no Ocidente, foi a religiosidade interior, culta, desenvolvida em âmbitos específicos, entre os quais as cortes (mesmo se não era a única que

11 O livro marcante desta renovação historiográfica é Eamon DUFFY, The stripping of the altars. Traditional religion in England, 1400-1580, 2. ed., New Haven e Londres, 2005; para um questionamento da leitura do Protestantismo inglês em termos de arcaísmo/ modernidade, Gordon MCMULLAN, David MaTTHEWs (eds.), Reading the Medieval in Early Modern England, Cambridge, 2009.

12 Paul Freedman, e Gabrielle SPIEgel, Medievalisms Old and New: The Rediscovery of Alterity in North American Medieval Studies, in The American Historical Review, 103/3 (Junho 1998), pp. 677 704; Garthine WALKER, Modernisation, in Garthine WALKER (ed.), Writing Early Modern History, Bloomsbury USA, 2005, pp. 25-48; Moshe SLUHOVSKY, Discernment of Difference, the Introspective Subject, and the Birth of Modernity, in Fournal of Medieval \& Early Modern Studies, 36/1 (winter 2006); pp. 169-199; Bruce HOLSINGER, Neomedievalism and international relations, in Louise D'ARCENS (ed.), The Cambridge companion to medievalism, Cambridge, 2016, pp. 165-179 (p. 167 ss.).

13 Norbert ELIAS, A sociedade de corte, Lisboa, 1995. Para una apreciação do conceito de «processo de civilização» e sua recepção, cfr. E. ANHEIM, Norbert Elias et le «procés de civilisation», in Ç. DELACROIX et al. (dir.), Histriographies, II. Concepts et débats, Paris, 2010, pp. 1127-1133. 
nelas existia). A junção das duas, entendidas como instâncias de controlo dos impulsos, conduziu inevitavelmente à descoberta e valorização de uma religiosidade de corte educada e culta.

$\mathrm{Na}$ verdade, estas leituras estão eivadas de uma valorização ideológica de índole progressista, que acarreta sérios danos à interpretação histórica como a que temos vindo a referir. As modernizações da espiritualidade tardo-medieval e prémoderna em geral - que são quase sempre sobretudo «espiritualizações (no sentido tradicional do termo) da espiritualidade» - têm impedido a correcta compreensão da religião como um fenómeno «imbebed», ou seja, inscrito em outras instâncias sociais, que por sua vez se inscrevem numa visão religiosa totalizante do mundo. Fenómenos que, ainda, se desenrolam, em sociedades em que o indivíduo era uma realidade bem diferente da inaugurada pelo iluminismo setecentista e continuada pelos regimes liberais oitocentistas, que o erigiram em unidade fundamental da sociedade, estilhaçando outras formas de organização, nomeadamente as corporações e os estatutos de sangue e de função, pelas quais passava, precisamente, a vivência da religiosidade. A religiosidade social, comunitária e agregadora, inspirada também nos modelos de organização próprios dos leigos (família, Casa, círculos de amizade), ou não é visualizada, ou é vista como um arcaísmo.

Um exemplo bastará para mostrar as consequências destas perspectivas. Particularmente afectada por esta visão, que é além do mais masculina e descendente da clerical, é a religiosidade feminina tardo-medieval, em que fenómenos como a oposição à observância orientada por homens, são considerados fruto da incapacidade de alcançar os lados cultos da mesma, por falta de leituras nomeadamente - obliterando as leituras femininas, cuja existência a historiografia mais informada tem realçado e que, no caso português do Mosteiro de Jesus de Aveiro, por exemplo, era corrente, e marcou de início um projecto devocional diverso daquele a que foram depois obrigadas as monjas, pela orientação dos confessores dominicanos... ${ }^{14}$. Ou, ainda, a insistência na manutenção de laços familiares nos conventos femininos, nomeadamente em termos de governação, que tem sido lida à luz da resistência tanto das estruturas de parentesco de sangue, a esse outro parentesco em que a Igreja se estruturou, e que depois quis estender aos leigos, o espiritual, como da permanência de mentalidades inigualitárias e valorizadoras do prestígio

14 Gilberto Moiteiro, As dominicanas de Aveiro (c. 1450-1525): Memória e identidade de uma comunidade textual, tese de doutoramento apresentada à FCSH/UNL, Lisboa, 2013. ID, Texto e experiência religiosas feminina: estratégias discursivas hagiográficas no seio da observância dominicana portuguesa, in João Luís FONTES et al. (coords.), Vozes da vida religiosa feminina. Experiências, textualidades e silências (sécs. XV-XXI), Lisboa, 2015, pp. 31-48. 
de berço social, em detrimento de «virtudes» como a sabedoria, a humildade, etc. $\mathrm{Na}$ verdade, em associações religiosas onde a disparidade de níveis sociais não é grande, nota-se a mesma tendência, que afinal, como dissemos, estruturava a organização dos leigos ${ }^{15}$; e não pode ser obliterado que o modelo de «abadessas virtuosas», com todas as boas intenções que possa ter tido, foi também uma construção de uma Igreja institucional, masculina e céptica quanto à capacidade feminina de liderança. Era nítido o mal estar e a resistências dos clérigos quanto à aceitação da supervisão de mosteiros de fundação feminina, sobretudo aqueles onde as patronas eram leigas poderosas, como foi o caso do convento da Rosa, em Lisboa, da Conceição, em Beja, de Jesus, em Aveiro, e de uma variedade de fundações mais pequenas, mas ricas, como a capela fúnebre de D. Isabel de Sousa, na Igreja de Santa Cruz do castelo, e Lisboa ${ }^{16}$. Toda a questão da integração das casas de fundação feminina ao longo do século XV deve ser lida como um processo de conformação disciplinar, e não como um glorioso avanço da religião «mais espiritual».

Para combater estas visões, é importante seguir propostas que, em primeiro lugar, analisam os contextos de leitura ideológica do Passado (começando pela própria reforma protestante inglesa) e que, depois, se inspiram em modelos não progressistas da análise social. Neste sentido, entre outros possíveis, parecemnos particularmente interessantes para o nosso tema as leituras de Eamon Dufy sobre a religiosidade inglesa das vésperas da Reforma, que colocam a enfâse na importância da religiosidade comunitária e dos contornos securizantes das devoções, ao mesmo tempo que alertam para o perigo de uma excessiva intelectualização da religião apenas porque ela se exprime através de formas que, mais tarde, são constituídas marcos da religiosidade e da devoção interiorizadas, cultas e/ou privadas - as leituras, a oração individual, a prática da confissão, a fundação de capelas fúnebres. É possível porém ler de outro modo, ou nas entrelinhas, estas formas de expressão, que precisamente têm grande sucesso nas cortes. Adiante no texto iremos tentar demonstrar como.

15 Joáo Luís FONTES, Em torno de uma experiência religiosa feminina: as mulheres da pobre vida de Évora, in Lusitania Sacra, 2. a s. 31 (Jan.-Jun. 2015), pp. 51-71.

16 Para o convento da Rosa e Isabel de Sousa, cfr. M. ${ }^{a}$ de Lurdes RosA, As almas herdeiras. Fundação de capelas fúnebres e afirmação da alma como sujeito de direito (Portugal, 1400-1521), Lisboa, 2012, pp. 384 ss. e pp.514-16; para a Conceição de Beja, ID., A fundação do mosteiro da Conceição de Beja pela Duquesa D. Beatriz, in O tempo de Vasco da Gama, dir. Diogo RAMADa CurTo, pp. 265-270, Lisboa, 1998; para Jesus de Aveiro, Gilberto MoITEIRO, As dominicanas de Aveiro (c. 1450-1525), cit., e M. ${ }^{\mathrm{a}}$ de Lurdes RosA, A religião no século: vivências e devoções dos leigos, in História Religiosa de Portugal, Ana M. ${ }^{a}$ Jorge, Ana M. ${ }^{a}$ Rodrigues (coord.), vol. 1, pp. 423-508, Lisboa, 2000 (pp. 501 ss.). 
Uma outra perspectiva de análise que vai ao arrepio da aceitação acrítica da «modernidade» destas práticas, assenta numa proposta interpretativa sobre a natureza da relação que a Igreja estabelece com a sociedade, a partir do arranque desse grande projecto de organização do mundo a que chamamos Reforma Gregoriana. Consiste na teorização da ecclesia medieval levada a cabo por Jérôme Baschet, Alain Guerreau, Anita Guerreau-Jalabert e Dominique Iogna-Prat: a «reorganização do mundo», pensada em Cluny e alargada pelos homens da abadia, em colaboração com Roma, a toda a Cristandade, tinha como fim último fazer coincidir a sociedade com a própria Igreja, num processo holístico e totalizante, que ganhava legitimidade na supremacia do espiritual sobre o material ${ }^{17}$. $\mathrm{O}$ «sistema eclesial» desenvolveu mecanismos próprios para se constituir em sistema total: uma prática omnipresente e constante de «articular os contrários», que permitiu anular o maniqueísmo, recusando a equivalência de poderes entre o Bem e o Mal; e como forma de obter a articulação, uma lógica de «rigor ambivalente» (a um tempo plástico, mas nunca tolerante para além de limites institucionais claros) ${ }^{18}$. Neste contexto, a articulação do espiritual e do carnal era um profundo modelo social, que resolveu o problema da Encarnação de Deus e permitiu a definição da Igreja como «corpo espiritual», como «instituição encarnada fundada sobre valores espirituais» ${ }^{19}$.

Ora, a recepção destas ideias pelos leigos, em especial os que detinham maior cultura e literacia, foi feita num sistema de apropriação em proveito próprio, e de modo cada vez mais autónomo. A desvalorização do estatuto laical, discurso central da instituição eclesiástica, raramente foi aceite de modo passivo, pese embora a conviç̧ão generalizada - que não era só oriunda do pensamento eclesiástico, estava presente na cultura clássica - da supremacia do espiritual sobre o material, da vida consagrada sobre a vida no século, das ocupações religiosas sobre as mundanas, do perigo da riqueza para a salvação. Na Baixa Idade Média, em especial, e em função também do desenvolvimento de posturas e grupos eclesiásticos que foram construindo uma espiritualidade mais consentânea com tal, os leigos já olhavam para a sua inserção no mundo como uma realidade não necessariamente condenatória. E, o que é mais importante, desenvolveram mecanismos próprios

17 Anita GUerreau-JaLABERT, L'ecclesia médiévale, une institution totale, in Les tendances actuelles de l'bistoire du Moyen-Âge en France et en Allemagne, dir. Jean-Claude SCHMITT, O.G. OEXLE, Paris, 2002, pp. 218-226; e o hors-série de BUCEMA (Bulletin du Centre d'Études Médievales) Auxerre, Les nouveaux horizons de l'ecclésiologie: du discours clérical à la science du social ( $\mathrm{n}^{\circ} 7$ I 2013).

18 Jérôme BASCHET, La civilisation féodale. De l'An mil à la colonisation de l'Amérique, Paris, 3 . $^{\text {a }}$ ed. corrig e actual., 2006, pp. 754-64 ; a última obra do A. retoma o tema, num aprofundamento da relação dual central, corpo e alma - Corps et âmes. Une histoire de la personne au Moyen Âge, Paris, 2016.

19 Jérôme BASCHET, La civilisation féodale, pp. 598 ss. 
de evitar os perigos, de beneficiar da intercessão da comunidade e da proximidade/ devoção aos santos, por fim, de transformar a perigosa matéria em salvíficos dons espirituais. A oração, as práticas caritativas, as dádivas, a inserção dos mortos na liturgia anual, a construção de capelas fúnebres onde se transformava a riqueza em sacrifícios eucarísticos, embelezamento do culto, assistência aos pobres - são todos mecanismos de assim fazer. Eles eram mantidos em funcionamento para esta operação que de algum modo era de «transubstanciação», por esse motor a um tempo social e religioso que era a «caridade». Esta, emanando de Deus, e definitivamente revertida em benefício da humanidade pecadora pelo sacrifício do Filho, era enriquecida e mantida a circular pelos «méritos»: um depósito inicial alcançado pela morte de Cristo, e que recebia acrescentos, em permanência, pelas acções generosas dos homens e do seu afastamento do mal e arrependimento ${ }^{20}$. A remissão dos pecados, que abria a porta à salvação, era feita a partir deste agregado de bens espirituais, numa circulação individual e social permanente.

No seguimento destas propostas, iremos aferir como a Corte lidou com a questão. Como veremos, para a Igreja, a corte era um local entre todos perigoso para a alma, um dos menos prováveis para realizar com sucesso esta operação. No entanto, para os leigos que nela viviam, tal era essencial, pois garantiria a salvação. Tentaremos demonstrar que a corte funcionou mesmo com um lugar de experimentação de formas próprias de a efectivar, «costumizadas» pelos leigos.

Em suma, o que as reconceptualizações e apreciações historiográficas que rapidamente revimos nos permitem pensar, é que a corte foi, antes de mais, uma zona de espiritualidade(s) construída(s), negociadas entre clérigos e leigos até nos seus aspectos mais doutrinais (como a natureza da relação confessional, a salvação, devoções disputadas como a Imaculada Conceição). Vejamos, então, alguns dos meandros desta relação dinâmica.

\section{LEITURAS DA «ESPIRITUALIDADE DE CORTE»}

\section{III.1. Os campos referenciais}

Como tentámos demonstrar em relação a um dos mais emblemáticos conteúdos da espiritualidade da corte portuguesa tardo-medieval, a fuga mun$d i$ - ou seja, a opção radical de abandonar a corte com a convicção que dentro

20 Anita GUERREAU-JALABERT, «Caritas» y don en la sociedad medieval occidental, in Hispania, LX/204 (2000), pp. 27-62. 
dela não seria possível a salvação da alma -, uma via para a compreensão destes fenómenos, que queira escapar a armadilhas das fontes e a leituras ideológicas posteriores, é a inserção dos mesmos numa consideração ampla de referenciais culturais $^{21}$. $\mathrm{O}$ motivo do abandono do mundo estava longe de existir apenas na esfera da decisão devocional pessoal (algo que em si mesmo não pode ser absolutizado, de resto). Ele permeava um conjunto de parâmetros de interpretação do mundo da época, e inseria-se em âmbitos mais vastos: modelos da relação alma/ corpo, modelos cavaleirescos, modelos cortesãos, desprezo de matriz clássica pelo poder. No aspecto ainda mais amplo da elaboração da sua relação espiritual com a corte e na corte, os cortesão dispunham de vários campos de referência, que concorriam activamente entre si, apesar da reclamação de supremacia (ou exclusividade) do eclesiástico. A corte deve assim ser vista como lugar de confluência e coexistência (reforçadora, conflitual, paradoxal) desses vários campos, ou significantes, da luta Bem/ Mal e da busca da remissão - salvação.

Para a detecção e análise dos mesmos, porém, temos que trabalhar dentro do acima referido alargamento de conceitos; não terá sentido, por exemplo, considerar a «aventura cavaleiresca» como um expoente da cultura nobiliárquica não religiosa, enquanto se classificam as «fugas ao mundo» como manifestações de anseios espirituais «propriamente ditos». Mas não bastará, para resolver a oposição, falar da clericalização dos rituais de cavalaria, ou da pietização do romance de cavalaria e dos seus heróis. Estas duas operações foram sem dúvida propostas de espiritualidade para os leigos, que requereram até grandes esforços para a sua promoção. Não foram porém oriundas da esfera laical, e a sua recepção benévola nesta está longe de ser provada, tal como, de resto, a aceitação unânime da Igreja quanto a estas operações ${ }^{22}$. A via que nos parece explicativa é a que considera no mesmo patamar a espiritualidade mais canónica e as espiritualidades próprias dos grupos leigos, entre as quais avulta, para a corte, a dos guerreiros - a sua forma específica de pensar a salvação -, que continuou a existir no seio da corte, onde recebeu outros influxos.

21 Maria de Lurdes RosA, Exercício do poder e salvação da alma: a «fuga mundi» na corte régia tardomedieval portuguesa, in Isabel BECEIRO PITA (dir.), Poder, piedade y devoción. Castilla y su entorno (ss. XII-XV), Madrid, 2014, pp. 423-451.

22 Como clássico no relançamento do tema, Georges DuBY, O cavaleiro, a mulher e o padre. O casamento na França feudal, Lisboa, 1988; síntese recente em Jean FLORI, Cavalaria, in Jacques LE Goff, J.C. SchmitT (eds.), Dicionário temático do Ocidente medieval, S. Paulo, 2002, vol. I, pp. 185-199. 
A visão eclesiástica: a corte como lugar de perigo

A consideração eclesiástica da corte, como se sabe, é a de um lugar de perigos extremos, tendo a Idade Média central - período onde aquela agremiação se laiciza e se torna o centro do poder - deixado, entre outros, o legado de Walter Map quanto à mesma como «lugar infernal». $\mathrm{O}$ inferno aqui, sublinhe-se, nem era tanto o perigo das tentações sexuais, de violência, ou de recta conduta: era a mistura, a desorganização ${ }^{23}$. Precisamente aquilo que a Reforma Gregoriana, a partir do grande cérebro que foi Cluny, tinha colocado como problema social central. «Organizar» (e logo depois «excluir») foi o grande objectivo dos cluniacenses, que o transmitiram, como leitmotiv, a um Papado em busca de um caminho de recuperação do o poder - o que só seria possível, assim, saindo da «confusão feudal $\gg^{24}$. A relação de Afonso Henriques com S. Teotónio, por exemplo, inscreveu-se neste sentido, na medida em que o Prior de Santa Cruz se assumia como mestre de um rei infantil, e como autoridade moral na corte ${ }^{25}$; da recepção do rei e dos cavaleiros a este modelo restam-nos vestígios dispersos, testemunhando uma aceitação bastante relativa ${ }^{26}$.

Entre os tempos iniciais e a corte tardo-medieval muito se passou, e a figura do Rei autonomizou-se da tutela eclesiástica, criando contornos sacrais, morais e religiosos próprios. A concepção da Corte como lugar moralmente perigoso, porque desordenado, continua porém a perpassar as fontes eclesiásticas que se referem a ela, ainda em pleno século XV. Desde logo, o perigo é imenso para os clérigos de corte, retratados como ambiciosos em busca de ofícios, benefícios e riquezas ${ }^{27}$. Mas também é real para os leigos, e a leitura da violência inerente às relações políticas coloca-se sempre em tons morais de aviso. Particularmente emblemáticos de tal são os escritos de Paulo de Portalegre, clérigo da Congregação de S. João Evangelistas (v. 1437-1510) sobre a execução do Duque de Bragança D. Fernando, por ordem régia (1483). Neles se equacionam os enormes perigos que correm os

23 Bernard GuenÉe, Corte, in Jacques Le Goff, J.C. SCHMiTT (eds.), Dicionário temático.., cit., vol. I, pp. 269-281.

24 Dominique IOGNA-PRAT, Ordonner et exclure. Cluny et la société chrétienne face à l'bérésie, au judaïsme et à l'islam, 1000-1150, Paris, 1988.

25 Uma apreciação muito cuidada da relação entre ambos em José MATTOSO, D. Afonso Henriques, Lisboa, 2006, pp. 128-130.

26 Maria de Lurdes Rosa, Por detrás de Santiago e além das feridas bélicas. Mitologias perdidas da função guerreira, in VI fornadas Luso-Espanholas de Estudos Medievais. A guerra e a sociedade na Idade Média. 6 a 8 de Novembro de 2008, Batalha, 2009, vol. II, pp. 383-404.

27 Rita Costa Gomes, A corte portuguesa no final da Idade Média, Lisboa, 1995, pp. 127-128. 
cortesãos, por culpa própria (ambição, desejo de poder) ou em função da inveja, vício que permeia as relações humanas na Corte. Sendo o escritor um homem próximo da Coroa, e tendo sido a sua Ordem particularmente favorecida por esta, cumpria-lhe porém a difícil tarefa de reabilitar a figura de um dos grandes protectores da mesma Ordem, que fora, além do mais, seu orientando espiritual. Assim, se bem que haja alusões mais ou menos veladas à cedência do rei à «lisonja», a figura central da diabolização são os «maus conselheiros», numa linha de argumento multissecular. O Duque redime-se do pecado em que possa ter incorrido, ao aceitar o modelo da boa morte cristã, que o seu confessor lhe propõe: humildade e despojamento, reconhecimento das culpas enquanto pecador e a vã glória do mundo. À Família que fica, o Duque aponta como caminho um simulacro do seu destino: o abandono do mundo. A Duquesa deveria entrar em religião, como sempre desejara; os filhos deveriam ser criados «pera Deos, e nenhum pera o Mundo». Pela boca de um dos seus maiores senhores, que conhecera o máximo poder e a máxima desventura, a corte é, aqui, totalmente rejeitada ${ }^{28}$.

A corte moral dos leigos literatos, dos escritos avisinos ao humanismo cristão

O moralismo de corte, florescente numa literacia específica, eminentemente leiga, encontrou Portugal encontrou clara expressão na corte de Avis, via corte inglesa dos Lancaster, nomeadamente ${ }^{29}$. O seu início corresponde a uma importante ruptura, em que os textos sobre a dimensão moral dos «estados sociais», dos cargos políticos e do ordenamento da sociedade em geral, deixam de ser monopólio de redactores eclesiásticos. A questão central da visão eclesiástica da corte - o perigo em que se encontra a alma dos que exercem o poder e a sua precaução pela recusa e abandono do mundo - percorre todos os escritos da Dinastia de Avis, tal como percorrera a corte dos Lencastre e seus círculos ${ }^{30}$.

28 Maria de Lurdes RosA, D. Faime de Bragança, entre a cortina e a vidraça in O tempo de Vasco da Gama, cit., pp. 319-332 (p. 324).

29 Como têm demonstrado os importantes trabalhos de Manuela Santos Silva sobre a Rainha, cfr., por último, Manuela Santos SILVA, A mother and her illustrious offspring: the role of Philippa of Lancaster, queen of Portugal, in her children's' education in Carey FleINER, Ellena WOODACRE (eds), Virtuous or Villainess? The role of the royal mother from the Early Medieval to the Early Modern Era, Nova Iorque, 2016, pp. 65-84.

30 Seja-nos permitido retomar parcialmente aqui a abordagem feita em Maria de Lurdes RosA, Exercício do poder e salvação da alma..., cit., p. 408. 
Assim, D. Duarte discorre sobre a vanidade do poder e a dimensão moral do cargo régio; D. Pedro preconiza que este seja exercido como uma «virtuosa benfeitoria», adoptando os modelos de redistribuição, reciprocidade, caridade e paternalismo como seus melhores fundamentos; a Infanta D. Catarina, filha do rei D. Duarte, recolhida em Lisboa no mosteiro do Salvador, teria traduzido o Livro da regra e da perfeição dos monges, de Lourenço Justiniano, autor que já fora fundamental à redacção do Leal Conselheiro. O seu tio D. Henrique mandara traduzir o Horologium Fidei. Entre os filhos do malogrado Duque de Coimbra, o Condestável faz o elogio do «desprezo do mundo» e a Infanta D. Filipa, retirada até à morte no mosteiro de Odivelas, teria também traduzido textos sacros e de espiritualidade, e chegado a compor obras de devoção. D. Pedro casara, relembre-se, com D. Isabel de Urgel, oriunda de uma das cortes onde o tema fora mais tratado e praticado, e de onde viera, como se sabe, Isabel de Aragão. As livrarias destes príncipes, como salientou Isabel Beceito Pita, continham livros de espiritualidade em número relevante. Mencione-se, por fim, o papel que estes senhores e senhoras desempenharam na tradução e edição de algumas das obras de espiritualidade que mais circulava nos meios frequentados e patrocinados por leigos devotos, ansiosos por uma participação de direito na Igreja - basta referir a Vita Christi, em cuja tradução D. Duarte poderá ter colaborado, e que era devida à pena de um cartuxo, oriundo de uma ordem a que pertenciam ou em torno da qual gravitavam, os clérigos ingleses que teorizaram a via mixta.

A partir das décadas finais do séc. XV, juntar-se-á a esta produção de literatura moral um outro tipo de escritos que com ela tem afinidades, embora os seus autores se situem numa outra esfera que não a dos próprios príncipes e princesas, mas sim a do seu serviço. Referimo-nos aos escritos dos humanistas cristãos, em que abundam reflexões e avisos sobre os perigos da corte. A exploração deste tema extravasa os limites do presente artigo, até em termos de cronologia, e implicaria um conhecimento mais aprofundado e actualizado da recepção do humanismo e intelectualismo cristãos na corte portuguesa, do que se encontra na historiografia disponível ${ }^{31}$. Mas tanto as continuidades em relação aos escritos anteriores, como o impacto que começaram a ter no período em estudo, justificam referência, mesmo se brevíssima. Erasmo, entre todos, via a corte como um local perigoso e desprezível, em especial para a religiosidade interior. Se esta

31 Seria necessário aprofundar, quanto à recepção mais amplas, estudos fundamentais como Luis de Sá FARDILHA, A nobreza das letras: os Sás de Meneses e o renascimento português, Lisboa, 2008. 
crítica acompanhava outras, dirigidas por sua vez aos problemas afins da Igreja institucional, e se situava assim nos campos reformistas, no que toca à corte ela contém laivos de tradicionalismo moralista; e, salienta Jorge Osório, que esta atitude não permitiu a Erasmo e a outros expoente do pensamento humanista cristão um aperceberem-se dos ganhos culturais da corte ${ }^{32}$. De algum modo, prolongava um moralismo eclesiástico convicto da sua superioridade.

\section{Batalhas sacras, lutas pela fé}

A par destas duas visões, que, apesar das suas diferenças, têm em comum mais facilmente se identificarem com o que o passou a ser, a partir do século XIX, a espiritualidade, existiam porém várias outras, que - raramente se recorda - continham fortes traços espirituais, morais ou religiosos. Anotamos, de modo breve, a permanência de valores sobrenaturais pagãos na visão religiosa do mundo nobre - que, mesmo se difusos no tempo corrente, em momentos fortes, como o rescaldo de Alcácer Quibir, literalmente invadiram a corte, sob formas muito pouco disfarçadas: sangrentos exércitos voadores, presságios e mensagens sobrenaturais de toda a ordem ${ }^{33}$. Mais clara e directa foi a relevância dada, pelo referencial guerreiro, a valores que, na ordem de ideias que temos vindo apresentar, devemos entender como espirituais: a honra, a fidelidade, a generosidade. Entre muitos outros exemplos possíveis, encontramos de tal acabado paradigma no comportamento de um Álvaro Vaz de Almada, em 1448 34 ; ou nas tradições familiares dos Sás do Porto, que recordam a cega fidelidade ao Rei, tingida de temeridade, de Rui Mendes de Vasconcelos de João Rodrigues de Sá, pouco depois traída pelos vis interesses da «política real» de D. João $\mathrm{I}^{35}$. Para além do valor espiritual em si, é importante referir que estas tradições familiares de honra, valentia e mesmo

32 Jorge A. OSÓRIO, Erasmo, a cortesia e a piedade, in Espiritualidade e corte em Portugal (séculos XVI a XVIII), Porto, 1993, pp. 7-22 (p. 21).

33 Maria de Lurdes RoSA, Mortos - «tidos por vivos»: o tribunal régio e a capacidade sucessória das «almas em glória» (campanhas norte-africanas, 1472-c. 1542), in Anais de História de Além-mar, VI (2005), pp. 9-46 (pp. 45-46).

34 Miguel Gomes MARTINs, Guerreiros medievais portugueses, Lisboa, 2013, pp. 319-353; Luís Adão da FONSECA, A morte como tema de propaganda política na bistoriografia e na poesia portuguesa do século XV, in Biblos, LXIX (1993), pp. 507-538.

35 Maria de Lurdes RosA, O corpo do chefe guerreiro, as chagas de Cristo e a quebra dos escudos: caminhos da mitificação de Afonso Henriques na Baixa Idade Média, in Santos e demónios na Idade Média Portuguesa, Porto, 2010, pp. 159-194 (p. 168). 
temeridade, eram facilmente transponíveis, prolongadas e reformuladas em comportamentos de espiritualidade bélica.

As tradições familiares de honra e valentia para além de toda a racionalidade, não estão de facto longe de algumas opções religiosas de «batalhas pela fé». Tal verificou em especial em grupos familiares estruturalmente ligados às ordens militares, com concentração no Sul do reino. O caso de Nuno Álvares Pereira foi um dos mais precoces e claros, mas também se deve olhar sob este prisma a família dos Silvas, de onde foram originários o Beato Amadeu e a sua irmã Beatriz da Silva. João da Silva de Meneses, mais tarde Fr. Amador ou Amadeu, que fora criado nos círculos da nobreza militar do Alentejo e Ceuta, pretendera, ao deixar o mundo vão da corte, alcançar o sacrifício nas terras mouriscas. Não será o menos enigmático deste senhores, criados entre a guerra, o proselitismo religioso e a ameaça de perder a alma, se conservando o poder. Seria de facto importante estudar a ligação entre os profetismos e o reformismo que teve capacidade de sedução nestes meios, olhando a guerra do Norte de África enquanto «nova Reconquista» - ocupação mais digna do que a política cortesã ou o comércio marítimo. Como veremos, toda a literatura ideológica da guerra norte-africana defende a ideia da restauração do domínio cristão. Era, sem dúvida, um terreno propício a entusiasmar jovens guerreiros educados na valorização da missão cruzada.

Já acima referimos, a propósito das dificuldades de interpretação devido à «pegada» eclesiástica, outro referencial a ter em conta - a extensão/ transformação dos ideais guerreiros pela cavalaria, nas suas configurações rituais, literárias e de ethos social. Na verdade, pese embora a forma como os clérigos utilizaram estas para fins de controle dos guerreiros e seus descendentes cortesãos, houve resultados surpreendentes quanto aos meandros da relação, em que a cavalaria devota inspira forma religiosas marginais, como foi o caso de São Francisco, cuja permeabilidade aos modelos da literatura épica e cortês, bem como a extensão daquela aos seus companheiros de «ordem», está bem estudada ${ }^{36}$; num outro quadrante, não menos interessante, temos alguns santos eremitas, entre os quais avulta São Galgano, o «eremita cortês». A questão aqui é ainda mais complexa, pois existiu uma ligação entre eremitas e cavaleiros errantes, em que os primeiros são os conselheiros privilegiados dos segundos, vindo com frequência a revelar-se seus tios - e pondo em evidência a força do parentesco carnal e da estruturação linhagística. E é um outro deserto, um espaço de franja da sociedade cada vez mais

36 Lise BATTAIs, La courtoisie de François d'Assise. Influence de la littérature épique et courtoise sur la première génération franciscaine, in Mélanges de l'Ecole française de Rome. Moyen-Age, t. 109, n 1, 1997, pp. 131-160. 
povoada, a floresta, que surge como palco deste itinerário espiritual/ parental, onde tão curiosamente se misturam os dois referenciais ${ }^{37}$. Por fim, as igrejas onde repousam cavaleiros, enchem-se de capelas e túmulos cujo epitáfios se louvam, a par e passo, as virtudes religiosas e as militares dos fundadores ${ }^{38}$.

\section{Uma espiritualidade da política}

Cumpre mencionar, por último, entre os referenciais de uma concepção alargada da espiritualidade de corte, os vectores espirituais, religiosos e morais que rodeavam e faziam funcionar a política. $\mathrm{O}$ tema será desenvolvido no seguimento do texto em torno da figura do rei, mas aqui é importante referi-lo enquanto parte do conjunto que temos vindo a analisar. $\mathrm{O}$ reforço do poder régio fez-se no Portugal tardo-medieval, e à semelhança de outros reinos do Ocidente, numa trajectória de aproximação e de apropriação de elementos religiosos muito fortes na sociedade de então, nomeadamente o perfil paternal, afectivo e redistribuidor de graças, de Cristo, da sua Mãe e da corte de adjuvantes celestiais com que os testamentos, por exemplo, nos permitem contactar na sua omnipresença ${ }^{39}$. Um exemplo claro de traço fundamental apropriado pela realeza à Igreja, é o do rei como protector da alma dos defuntos, que causou não poucos atritos entre os monarcas de Avis e o clero português, e culminou na criação de órgãos próprios de acção da Coroa, numa esfera que até então lhe fora estranha ${ }^{40}$. Este exemplo permite-nos realçar um aspecto fundamental do que podemos chamar uma «espiritualidade política», construída pelos leigos - tinha que ser eficaz em termos de poder, tinha que resultar num acréscimo do mesmo. É o sentido que tem uma prática raramente encarada sobre este ângulo, mas que era difundidíssima e jogava grande papel na corte: o mecenato religioso por encomenda régia, a que voltaremos na última parte do texto. Era importante dar, doar, proteger, mas tal tinha que ter uma eficácia política, resultando em agrado régio. Vejamos, em pormenor, os contornos destas questões.

37 Eugenio SUSI, L'ermita cortese. San Galgano tra mito e storia nell'agiografia toscana del XII secolo, Espoleto, 1993.

38 Luís PONTES, Do mundo da corte ao mundo da memória - subsídios para o estudo da mentalidade cavaleiresca da nobreza portuguesa, Lisboa, diss. de mestrado apres. à FCHS-UNL, 2008; o tema foi retomado, com um conjunto mais vasto de fontes, por Miguel AGUIAR, Ideologia cavaleiresca em Portugal no século XV, Porto, diss. de mestrado apres. à FL-UP, 2016.

39 Maria de Lurdes RosA, As almas herdeiras..., cit., pp. 165 ss.

40 Maria de Lurdes Rosa, As almas herdeiras..., cit., p. 168. 


\section{III.2. A figura religiosa do rei}

De facto, o núcleo central da espiritualidade na corte era o rei, nas relações que estabelecia com esse campo religioso específico, mas também, a partir dele, com o reino e a Igreja. Verificou-se, com efeito, uma permanente construção religiosa interna e externa do monarca tendo em conta estes contextos, e ela foi determinante para o processamento das restantes relações dentro do campo. A figura religiosa e espiritual do rei deve assim ser analisada em pormenor, embora não no sentido de uma disseminação de modelos «de cima para baixo», mas antes em relação com aquilo que definia a sua função mesma: a detenção do poder. Tal colocava a figura religiosa do rei no centro, sem dúvida, mas este era um centro permanentemente vigiado e reconstruído, porque o supremo poder constituía o supremo perigo para a alma e tinha afinal que ser invertido para garantir a salvação do Rei. Ao longo do século XV, em continuidades com algumas tendência anteriores, mas sob o influxo seja de novas teorias do poder régio (nomeadamente o paternalismo), seja das vicissitudes históricas concretas - a viragem de costas ao bloco peninsular com o advento de D. João I e a saída atlântica - os reis de Portugal encarnaram sucessivos papéis religiosos e espirituais que marcaram profundamente as suas cortes. Como vamos ver, a maior parte destes papéis inscrevem-se numa construção de espiritualidade própria, onde os elementos da doutrina cristã são omnipresentes, claro, mas onde a maneira de os organizar e combinar com outros referencias, é fortemente leiga, e não raras vezes, em confronto com os eclesiásticos.

\section{O rei cruzado peninsular}

A tradição dos primeiros séculos de existência de Portugal como reino independente, até à conquista definitiva do Algarve em 1249, pôs acento na dimensão cruzadística do poder régio. Após um período de alguma latência, em que avulta porém o episódio do Salado (1340) - mas em cujas narrativas o protagonismo régio é bem menor do que o das Ordens Militares ${ }^{41}$, é em torno de uma rememoriação/ invenção de uma primordial batalha contra cinco reis mouros, em Ourique, que em parte se reorganiza a reacção aos castelhanos, na quase fatal crise

41 Bernardo Vasconcelos E Sousa, O sangue, a cruz e a coroa. A memória do Salado em Portugal, in Penélope. Fazer e desfazer História, 2 (Fevereiro 1989), pp. 28-48 
dinástica de 1383. Segundo as investigações recentes, a lenda é um produto eclesiástico, proveniente de Santa Cruz de Coimbra, convento dos primeiros reis por excelência, e que assim se lança numa tentativa de recuperar a perdida influência. Se incluiu uma pietização do rei, outras componentes das tradições relativas a Afonso Henriques em Santa Cruz Cruz de Coimbra tinham origem diversa - a queda do escudo pendurado junto ao túmulo régio, cada vez que morre um rei de Portugal, tem como pano de fundo a ligação entre o corpo dos guerreiros e as suas armas, de origem pré-cristã ${ }^{42}$. De resto, em quase todas as recriações da figura régia no mosteiro é possível encontrar incongruências que deixariam cauteloso qualquer eclesiástico culto e ortodoxo; estas, do maior interesse para o historiador, resultam da presença de elementos oriundos de outros campos de significado, cuja força é de molde a resistir às formatações eclesiásticas. O que elas revelam é a perenidade da figura do rei que os elementos épicos remanescentes também acusam: como campeão da Cristandade, porque conquistador de terras ao inimigo religioso, à custa do seu próprio corpo, e como fiel cristão («tão boos livros temos nos aca como vos em em Roma»), mesmo se nem sempre acatando as ordens eclesiásticas e até mesmo opondo-se-lhe com violência, se necessário ${ }^{43}$.

Será porém a partir de Ceuta que a monarquia investe decisivamente numa recuperação da figura do rei promotor de cruzada, numa modalidade própria com grande interesse. Sempre em concorrência com os outros reinos ibéricos, em particular Castela, a Dinastia de Avis tinha no momento, porém, uma vantagem sobre esta. A vitória de Aljubarrota garantira a um rei adventício uma legitimidade militar, e as resoluções das cortes de Coimbra tinham procurado assegurar a legitimidade política ${ }^{44}$. São conhecidos os recursos de carácter religioso em que D. João I e o seu herdeiro basearam a legitimação da ascensão ao trono, avultando entre eles a qualificação de «Messias de Lisboa» na crónica do reinado, mandada escrever por D. Duarte (e a este carácter messiânico voltaremos mais tarde). Se a partida para Ceuta encontrou entre outras razões a ideia de expiação de culpas régias - no caso, a das mortes causadas entre Cristãos, nas batalhas pela independência do reino-, este aspecto negativo foi menorizado em relação à continuidade da Reconquista, e da Cruzada em geral, que presidiu à empresa desde

42 Sobre toda esta questão, cfr Maria de Lurdes RosA, O corpo do chefe guerreiro..., cit..

43 A reconstrução da perdida épica de Afonso Henriques foi primeiramente realizada por António José SARAIVA, A épica medieval portuguesa, Lisboa, 1979; a frase citada provém da entrevista entre Afonso Henriques e o Cardeal Legado (ibid., p. 41).

44 Sobre o reinado de D. João I, Maria Helena CoElHo, D. Foão I. O que re-colheu «Boa Memória», Lisboa, 2008. 
o início. Pelo contrário, a derrota de Juan I, que causara além do mais a morte de muitos dos seus cavaleiros, foi vivida de modo extremamente negativo pelo monarca e sua entourage, implicando um paralelismo com o perene fantasma que sempre pendeu sobre os monarcas castelhanos, a «perda das Hespanhas», e com outros imaginários de expiação de culpas ${ }^{45}$.

Desde o seu inicio que a investida militar no Norte de África foi pensada como Cruzada. Ch.-Martial de Witte defende, com pertinência, que a primeira expedição da Dinastia de Avis a África (Ceuta, 1415) foi caucionada por uma bula de cruzada, apesar de se desconhecer o teor do documento, perdido ${ }^{46}$. A cronística relata que a bula foi lida em Lagos, à frota que se preparava para partir. Para além do sermão solene, não terão existido outras celebrações, sendo a ausência explicada pelo secretismo com que se quisera envolver a expedição. Conhece-se no entanto esse sermão, pregado pelo capelão régio, Fr. João de Xira, depois incluído na Crónica da Tomada de Ceuta. O clérigo fizera parte do grupo de letrados consultados pelo rei sobre a legitimidade da expedição, que a garantira por meio de vários argumentos, um dos quais o paralelo entre a luta cruzadística de Afonso Henriques e a acção militar prevista por D. João I. No momento da publicação da bula, o seu sermão insiste em especial em duas grandes ideias: por um lado, está-se a lutar numa Guerra Santa, com carácter redentor; por outro, é uma guerra justa, uma vez que os cristãos mais não fazem do que recuperar territórios usurpados à sua fé pelos muçulmanos. A prédica termina, significativamente, com o episódio dos Macabeus - tópico clássico da heroicidade e do martírio dos guerreiros, que teve um importante papel na formação da ideia de Guerra Santa. Estes temas são retomados num outro momento sacro solene, o sermão de acção de graças pela conquista da cidade. Depois da purificação e consagração da mesquita em igreja, na presença do rei e dos principais senhores da corte, o capelão régio centra a homilia da primeira missa no tema da glória dos combatentes pela fé. Celebra, ainda, a conquista da cidade como o início da recuperação de África pelos Cristãos, retomando o tema das cinco chagas de Cristo através da associação simbólica destas ao nome da cidade, com cinco letras. A cerimónia encerra com o importante evento da investida cavaleiresca dos Infantes e de muitos jovens cavaleiros nobres, realizando-se assim o desejo dos Infantes de Avis: associar a sua entrada na cavalaria à Guerra Santa,

45 Sobre isto, sempre em paralelo com o caso português, cfr. o excelente estudo de César OLIVERA SERRANO, Las sequelas religiosas de un conflito dinástico: portugueses en Castilla en el siglo XV, in Isabel BECEIRO PITA, Poder, piedade y devoción.., cit., p. 161-188.

46 Retomamos aqui parcialmente o nosso estudo Mortos «tidos por vivos»..., cit. (ponto 2.2). 
pois só ela daria verdadeiro significado ao uso das armas pelos guerreiros. A «cavalaria» dos Infantes portugueses é, especificamente, uma cavalaria de cruzada, o que a diferencia das alcançadas em teatros de guerra entre cristãos, por muito prezadas que fossem as proezas dos cavaleiros.

Seria possível prosseguir com vários outros exemplos da configuração régia do rei de Portugal como cruzado, ao longo de todo o século XV, através de diferentes mecanismos: a cronística, as cerimónias de intercessão e celebração, a promoção de santidades e exemplaridades, textos de propaganda diplomática, teatro, forma de apropriação e nomeação dos novos espaços. Por limitações de espaço, e porque já abordámos o assunto em extensão noutros locais ${ }^{47}$, insistiríamos aqui no que nos parece uma pedra de toque e uma diferenciação proposita$\mathrm{da}$ - a Cruzada portuguesa quatrocentistas era norte-africana para se opor - ou pelo menos afirmar em relação a - duas outras cruzadas que faziam sombra ao papel que assim encarnava o rei português. Por um lado, a castelhana, relançada com a conquista de Antequera em 1410 e que disporia ainda, ao longo de décadas, de uma larga fatia de território muçulmano a conquistar, no prolongamento das suas fronteiras; por outro lado, a hierosolimitana, intermitentemente relançada pelo Papado e, logo, muito menos controlável. O Norte de África foi assim constantemente recriado como antigo território cristão, que os reis de Portugal restauravam para a primitiva fé, podendo com plena razão espiritual arrogar-se a deter um reino «além-mar em África». Mais, esta razão era até eclesiástica: não só Fr. João de Xira, como dissemos, trabalhara com o rei para legitimar juridicamente a invasão como uma cruzada, como as dioceses criadas não fora entendidas como novas, mas sim como «restauradas». A recuperação portuguesa da «Cristandade africana» foi sistematicamente feita em relação à recuperação dos territórios onde haviam vivido e pregado grandes santos, avultando entre eles Agostinho, que detinha também a qualidade de «natural» da terra. E não foram descurados outros elementos «ponte», menos eruditos mas certamente mais impactantes, como a reutilização, com purificação, de sinos provenientes de igrejas saqueadas em Lagos, anos antes da conquista de Ceuta, encontrados em mesquitas desta cidade (motivo repetido noutros locais, como Azamor e Marraquexe) ${ }^{48}$.

47 Em estudo agora reunidos no volume Longos sonhos, longas guerras africanas. Da tomada de Ceuta ao fim do Império, Porto, 2010, para o qual tomamos a liberdade de remeter.

48 Maria de Lurdes RosA, Velhos, novos e mutáveis sagrados... Um olhar antropológico sobre formas «religiosas» de percepção e interpretação da conquista africana (1415-1521), Lusitania Sacra, 18 (2006), pp. 13-85 (pp. 52 ss.). 
O rei messias e a cruzada de Jerusalém

A cruzada de Jerusalém, forçada a uma maior conformidade com os modelos eclesiásticos - e a enquadramentos diplomáticos mais complexos e difíceis -, só muito mais tarde, com D. Manuel, veio a revestir importância acrescida nos caracteres religiosos do monarca português - e mesmo então, em função de um protagonismo deste, que passava pelo longo desvio indiano. Este, se não era desconhecido $^{49}$, fora tornado possível pelas conquistas portuguesas e pela manutenção das mesmas pela força. Não interessa aqui tanto que não tivesse sido considerado realista por largos sectores da sociedade, mas sim que, mais uma vez, se baseava na força militar e política, que assim se apropriava do mítico prestígio do resgate da Terra Santa. A parada tinha subido muito, com a conquista de Granada e a gigantesca propaganda religiosa que os Reis Católicos tinham feito a partir dela, apresentando-a como a purificação de um espaço profanado, como a recuperação, por fim, da derradeira parte das perdidas Hespanhas - e a concomitante abertura de um novo espaço cristão, esplendoroso e triunfante, à imagem, dos soberanos ${ }^{50}$. As circunstâncias internas de Portugal eram também bem diferentes, e maior a internacionalização da importância do reino; tal permitiu a D. Manuel reconfigurar a sua figura régia religiosa e espiritual com acrescida ambição.

Reclama novamente para a realeza uma aura messiânica, que encontra expressão em muitos aspectos da simbólica e da mitificação do seu poder ${ }^{51}$ e é muito mais forte do que a metáfora de Fernão Lopes em relação a D. João I. Rodeado de alguns fiéis, entre os quais avultou Duarte Galvão, com ligações a Santa Cruz de Coimbra e a toda a projecção da figura de Afonso Henriques que se fez a partir do mosteiro - eclesiástica ou «para-eclesiástica» - o Venturoso procurou estender o seu campo de rei cruzado do Norte de África (onde manteve diversas acções nesse sentido $^{52}$ ao rei cruzado de Jerusalém, agora campeão da Cristandade contra os

49 Jacques PaVIOT (dir.), Les projets de croisade. Géostratégie et diplomatie européene du XIVe au xviie siècle, Toulouse, 2014.

50 Miguel Luis LóPez GuAdalupe MuÑoz, Primeras devociones en la Granada conquistada por los Reyes Católicos: la tradición cristiano-vieja, in José Antonio PEINADO GUZMÁN, María del Amor RODRÍGUEZ MiRANDA (coord.), Meditaciones en torno a la devoción popular, Cordova, 2016, pp. 9-30.

$51 \mathrm{O}$ estudo de fundo sobre este aspecto é Luis Filipe ThOMAZ, Lidée impériale manuéline, in La Découverte, le Portugal et l'Europe. Actes du Colloque, Paris, 1990 pp. 35-103.

52 De facto, o interesse no Norte de África recrudesceu com D. Manuel, apesar das suas preocupações com outas legitimidades, cfr. Maria de Lurdes ROSA, Mortos «tidos por vivos»..., cit., p. 23, pp. 41-43. 
$\operatorname{Turcos}^{53}$. E, tal como em vários outros aspectos, D. Manuel prossegue acções de D. João II, delas beneficiando. As expedições patrocinadas por este rei em busca do Preste João tinham resultado no relativo sucesso do conhecimento do reino da Etiópia e da aliança dos Portugueses com o mesmo. D. Manuel irá investir fortemente nesta relação, através de uma catequização e de uma difusão de «leituras espirituais» com recurso ao mais moderno meio da época, a imprensa. Em 1514, o rei manda reunir um vasto conjunto de presentes para enviar ao Prestes João, todos de recente impressão: a Estoria do mui nobre Vespasiano, o Flos Sanctorum, e os Feitos e Paixões dos Santos Mártires, de Bernardo de Brihuega. No âmbito catequético, são enviados cem «Livros de horas de Nossa Senhora, em linguagem»; mil «cartinhas», ou seja, pequenos catecismos com as orações principais, trinta «catecismos» (seguramente a recente edição de 1502, de D. Diogo Ortiz, capelão régio); e cem exemplares do Breve memorial dos pecados, de Garcia de Resende (também edição recente, de 1512) ${ }^{54}$.

O rei evangelizador dos pagãos e a criação de cortes devotas em África

Se reforçou a figura régia com base em antigos modelos - restaurador da Cristandade norte-africana, salvador das isoladas cristandades míticas do Prestes, resistente do sonho de Jerusalém - a Coroa joanina mas, em especial, a manuelina, não se ficou por aí. Pela evangelização do Congo, pelo Padroado e pela ação jurisdicional da Ordem de Cristo, anexada à Coroa depois de 1472, os monarcas lusos abriram novas estradas de espiritualização e de enquadramento religioso da sua figura: evangelizador dos pagãos e conquistador, para a Cristandade, de vastas zonas que pela primeira vez era enquadradas no tempo e no espaço cristãos ${ }^{55}$. Desenvolvermos aqui o tema da relação estabelecida entre a Coroa portuguese e o Reino do Congo, tão pouco conhecida, quanto exemplar ${ }^{56}$.

Estão estudadas as diversas formas «objectivas» de que se socorreram os reis D. João II e D. Manuel (com o filho deste a completar-lhe as iniciativas) para estabelecer no Congo um reino cristão de raiz, com uma organização político -administrativa e uma estrutura religiosa em tudo semelhantes à da corte e igreja

53 Luis Filipe ThOMaz, L'idée impériale..., cit.,

54 Maria de Lurdes RosA, Sagrado, devoções e religiosidade, cit., pp. 381-83.

55 Maria de Lurdes Rosa, Velhos, novos e mutáveis..., p. 36 ss.

56 As linhas que se seguem sumariam o essencial da nossa mais alargada abordagem ao tema em Maria de Lurdes Rosa, Velhos, novos e mutáveis..., p. 19 ss. 
portuguesas. Nestes dois reinados, foram enviadas várias embaixadas, munidas de instruções minuciosas e de grandes quantidades de material e de pessoal diverso, dos livros aos recursos humanos, quase «kits de bricolage» destinados a criar exnovo um reino luso em terras de África. Após alguma estabilização, seguem-se os regimentos destinados ao funcionamento das novas instituições que se esperava terem sido entretanto criadas: corte, tribunais, escolas, estruturas eclesiásticas. Ao mesmo tempo, o acolhimento em Lisboa de jovens da família real e nobreza, bem como uma intensa correspondência com o Rei do Congo, tentam cimentar laços mais pessoais e familiares, além disso reforçados através do parentesco artificial do apadrinhamento.

Interessa-nos aqui agora evocar uma modalidade «subjectiva» de criação de relações com o reino cristão do Congo: a «construção de patronato celestial» para o novel território cristão, no qual, de acordo com a mentalidade dos recém-chegados, se travava de facto um combate entre os deuses locais, encarados como terríveis e assustadores ídolos, e a verdadeira divindade, por eles anunciada. A construção desta protecção passou por um processo evolutivo muito interessante, nos poucos anos que mediaram as primeiras iniciativas, em 1491, e 1512, quando se oficializa a referência ao milagre operado em benefício de um dos pretendentes ao trono do Congo, o príncipe convertido - milagre esse operado, nada mais, nada menos, do que por Santiago (numa das versões) e pelo próprio Cristo Crucificado, noutra. O ponto de partida devocional é Santa Maria, devoção que é proposta aos evangelizandos, e que coincide com o orago da primeira igreja fundada no novo território; nos relatos mais antigos dos cronistas portugueses, os primeiros baptizados teriam afirmado ter visto uma «mulher belíssima», que lhes transmitira uma promessa de auxílio do Rei de Portugal, caso se convertessem; noutro passo do relato, alguns dos convertidos encontram, depois do baptismo, uma cruz em pedra negra, de perfeito lavor, que é colocada na igreja. Já aqui, apesar da centralidade de Maria, a cruz começa a ganhar importância, e virá tornar-se o elemento principal, obliterando a figura feminina e, ainda, convertendo-se em cruz de Guerra Santa. O texto seguinte, a mais antiga versão da Crónica de D. Foão II, de Rui de Pina, narra uma partida para a guerra contra os membros da corte que continuavam pagãos, em que o exército é liderado por um alferes-mor (demonstrando já a adopção dos modelos de organização da corte e administração portuguesa), que leva uma estandarte da cruz, e entoa o hino «Vexilla regis prodeunt», em toda a sua extensão. Em testemunhos posteriores, a cruz torna-se decisivamente uma cruz de cruzada. O humanista João de Barros, nas Décadas (1563), dá um passo decisivo, ao referir que a bandeira entregue ao rei congolês pelo chefe da expedição portuguesa 
«que lhe mandava el rey que era da sancta cruzada, que lhe concedera o papa Jnocencio octauo pera a guerra dos infiées» ${ }^{57}$. Até então não existe semelhante associação, pelo menos de modo tão explícito. Em 1512, por fim, dois documentos emanados da corte de D. Manuel, um «Regimento» e uma carta de brasão, referem o milagre fundador da realeza cristã do Congo, doravante reinando sem equívoco sobre os pagãos. A oscilação quanto à divindade adjuvatória - Santiago ou Cristo - poderia remeter para distintos milagres fundadores de realezas peninsulares, a de Ramiro I em Clavijo e a de Afonso Henriques, em Ourique; porém, é a Cruz de Cristo que adquire maior importância, pois Santiago nunca é referido sozinho, mas sempre com ela, ao passo que se reporta uma aparição somente da cruz. Parece-nos, assim, que o referencial central é realmente Ourique, aparecendo Santiago como o padroeiro tradicional dos cruzados peninsulares, sempre invocado em batalhas (como fazia na Índia, pela mesma época, o vice-rei Afonso de Albuquerque, devoto cavaleiro da Ordem santiaguista). Na carta do brasão concedido ao rei do Congo, encontra-se um trecho que não só liga, em termos de substância, as armas doadas às do rei doador, como contém uma menção à forma como os reis de Portugal as tinham obtido, mimetizando Ourique e geminando portanto os milagres de fundação.

O rei protector das almas, promotor da devoção dos súbditos e reformador dos vícios eclesiásticos

O perfil religioso e espiritual dos reis de Portugal, ao longo do século XV, vai revestir-se de diversos outros papéis, todos do maior interesse ${ }^{58}$. D. Duarte encarnou com suma mestria a figura do rei moral e paternal, que entende dever estender a sua função à protecção das almas dos súbditos - vivos e mortos - e aos próprios bens espirituais, assegurando-se que são bem geridos e redistribuídos, até contra os próprios eclesiásticos. Esta função é continuada pelo filho, que continua as acções do Pai sobre capelas e legados pios, e em cujo reinado se desenvolve enormemente, por exemplo, uma instituição ainda mal estudada mas que é um exemplo claríssimo da transformação do material em espiritual, com limitações morais no processo: a Arca da Piedade. Com D. João II, é na reforma

57 João de BARros, Década I, livro III, cap. IX (ed. de António BAIÃo, L. F. Lindley CINTRA, Lisboa, 1988, vol. I, p. 106).

58 Para uma descrição e análise extensa dos mesmos, Maria de Lurdes RosA, As almas herdeiras..., cit., pp. 165 ss. 
das instituições pias e dos hospitais, enorme empreendimento, levado a cabo com a colaboração de um punhado de próximos colaboradores eclesiásticos e leigos, que se consubstancia esta vertente do poder régio. Com D. Manuel, por fim, na opulência do seu reinado, o rei moral prossegue a reforma hospitalar, patrocina a criação dessas impressionantes confrarias quase totalmente leigas, que são as Misericórdias, nas quais não obstante se concentrará a mais fervorosa devoção, nos séculos seguintes, incrementa ou desenvolve cultos vários, como à Rainha Isabel de Aragão (beatificada em 1516) ou ao Anjo Custódio, interessantíssimo programa que realiza a extensão da protecção do corpo do Rei ao reino como corpo $^{59}$. Não menos importante nesta vertente da figura religiosa e espiritual do rei, é a característica de rei reformador da Igreja, ou pelo menos da Igreja viciosa: a protecção das observâncias, iniciada por D. João I num contexto de providencialismo $^{60}$, será uma constante até final do reinado de D. Manuel, causando não poucos problemas na relação com a Igreja, mas avançando de forma imparável, até pelo recurso à dádiva cortesã, a que já aludimos e a que voltaremos em maior pormenor em baixo ${ }^{61}$.

Cerimónias de corte e figuras régias de fronteira

A exposição completa da figura religiosa dos Reis de Portugal no período tardo-medieval implica a referência a dois outros campos, bastante distintos entre si, mas igualmente produtores de significados fundamentais. Os limites do artigo impõem-nos uma mera menção, que contudo não deixaríamos de fazer, por preocupação de completitude, e porque permite remeter para estudos disponíveis sobre o assunto. Temos, por um lado, o rei nas cerimónias oficiais de corte - na capela régia, nas entradas régias, no cerimonial fúnebre da realeza. Pese embora a sua importância, são as instâncias menos espontâneas e menos dotadas de criatividade própria, do conjunto que circunscrevemos, por obedecerem a uma etiqueta cada vez mais «europeia» e codificada a partir de «cerimoniais» políticos gerais,

59 Maria de Lurdes Rosa, O Estado manuelino. A reforma de capelas, hospitais, albergarias e confrarias, in O tempo de Vasco da Gama, cit., pp. 205-210; Ana Cristina ARAÚJO, Cultos da realeza e cerimoniais de Estado no tempo de D. Manuel I, in Actas do III Congresso histórico de Guimarães: D. Manuel e a sua época, Guimarães, 2005, vol. IV, pp. 71-94.

60 Cesar Olivera Serrano, Las sequelas religiosas de un conflito dinástico..., cit., p. 163.

61 Um largo panorama das reformas eclesiásticas, também na relação com a monarquia, pode ver-se em José A. de Freitas de CARVALHO, Antes de Lutero: a Igreja e as reformas religiosas em Portugal no século XV. Anseios e limites, Porto, 2015. 
bem como, evidentemente, por funcionarem com forte enquadramento eclesiástico. Foram já objecto de cuidadosos estudos ${ }^{62}$. Em segundo lugar, destacam-se os perfis religiosos do rei que ganham interesse por se situarem nas fronteiras dos vários campos referenciais que temos vindo a estudar ${ }^{63}$. São eles o rei em fuga e o «rei menino», o rei peregrino anónimo, e o rei milagroso (referindo-nos aqui a milagres não certificados pela Igreja, total ou parcialmente). A vertente de folclorização destas figurações tem sido destacada, mas é preciso ser cauteloso na alocação do adjectivo de «popular», que as contraporia, por exemplo, às referidas de início. Por exemplo, a «inversão de papeís» e a «roda da fortuna» eram metáforas presentes a um tempo na cultura erudita e nas festividades populares de tipo carnavalesco. A miraculização dos reis, por seu lado, é também um fenómeno complexo, pois a devotização da figura régia que a Igreja a certa altura admitiu, rivalizou sempre, nos processos de canonização, com as ideias de fundo pagão das «santidade dinástica» ou seja, transmitida por sangue; e entra aqui ainda, claramente em reis como Afonso Henriques e, em menor grau, D. João I, o elemento das forças sobrenaturais dos guerreiros. Enfim, o facto de alguns destes atributos situarem numa fronteira incerta entre santidade e magia, como era o caso dos poderes curativos, trazia tanto prestígio à figura, quanto problemas a um outro tipo de política régia. $\mathrm{O}$ caso de $\mathrm{D}$. Afonso V é paradigmático. As fugas do rei, se bem que altamente complicadas para o herdeiro, foram de molde a criar ecos sobre a natureza santa daquele. Segundo o testemunho da crónica de Andrés Bernaldés, teriam corrido extraordinários rumores sobre D. Afonso V, à sua morte - que ele não falecera, mas sim que partira para Jerusalém, em penitência do seus erros, ou, ainda, que se fizera frade e fora em peregrinação a Roma e a Compostela. Estas notícias, referia o cronista, justificavam-se pela ideia corrente de que ele não suportara os erros cometidos, uma vez que tinha sido de grande virtude, caritativo e devoto, chegando alguns a atribuir-lhe poderes extraordinários, como o de curar doentes (em especial os afligidos de escrófulas, qual versão ibérica e tardia de monarca capetíngio) com a imposição das mãos. Segundo a mesma crónica, a Coroa atalhou de forma severa a circulação destas ideias, declarando-as alvo de pena de morte.

62 Rita Costa Gomes, A corte dos reis de Portugal..., cit., pp. 295 ss.; e Ana Cristina Araújo, Cultos da realeza e cerimoniais de Estado..., cit.; Maria Helena COELHO, The Royal Chapel during the reign of King 7oão I (1385-1433): the role of clergymen, in Cuadernos de Estudios Gallegos, 62/128 (2015), pp. 83-105.

63 Aludiremos aqui aos aspectos mais importantes, remetendo, quanto ao aprofundamento do tema, para Maria de Lurdes RosA, Exercício do poder e salvação da alma..., cit., pp. 436 ss. 


\section{III.3. Espiritualizar a matéria e fazer circular a caridade - «ao modo cortesão»}

Como referimos no início deste estudo, a corte régia tardo-medieval é particularmente interessante como campo de observação dos processos sociais de espiritualização da matéria e de circulação da caridade. Os traços culturais dicotómicos que temos vindo a estudar para tal concorrem - a preocupação com a salvação da alma, colocada em perigo por um ambiente de luxo; a capacidade de obviar à perda, pela inversão da riqueza; e um ethos generalizado de dom e dádiva, tidos como elementos essenciais para, por um lado, alcançar o favor régio, mas propícios também a precaver os efeitos nocivos daqueles objectivos mundanos para a vida espiritual. Podemos assim interrogarmo-nos: a corte lidou de modo próprio com estes perigos e vantagens? E como resolveu a dicotomia?

Definimos dois grandes campos para responder tal. Em primeiro lugar, a identificação de grandes campos de espiritualização da matéria, as «cortes ocultas», os espaços de devoção «privada» e as relíquias; depois, a caracterização do que nos parece ser uma específica circulação social da caridade, que definimos como «dádiva constrangida».

Corte oculta, corte austera, recusa da corte

Entre as mais claras formas de espiritualizar a matéria em ambiente cortesão, estiveram as práticas de mortificação, tão mais valiosas se ocultas, porque recusando a componente de admiração pelos pares que tanto norteava o sucesso em corte. A princesa Joana, segundo a hagiografia redigida no Mosteiro de Jesus de Aveiro, retirava-se todas as noites para uma pequena, esconsa e desconfortável câmara secreta que mandara fazer debaixo do luxuoso quarto onde as damas a despiam e deitavam; e usava uma áspera penitência por debaixo dos ricos vestidos de princesa ${ }^{64}$. Outras manifestações deste tipo de atitude, como as camisas sujas, os cilícios, as práticas de jejum e de morigeração que, após as mortes, ou em circunstância extremas, como a prisão após a fuga, são descobertas nas mais altas figuras da corte. Sobre D. João II, relata Garcia de Resende, o seu cronista, que praticara durante todo o seu reinado o ascetismo privado, e que quando, após a sua morte, os dois fieis servidores que eram o Bispo de Tânger e o Prior do Crato, escondidamente abriram uma caixa que trazia sempre consigo, para elimi-

64 «Memorial da mujto excellente Princessa Dona Joana», ed. in Domingos Maurício Gomes Dos SANTOS, O mosteiro de Jesus de Aveiro, vol. II/2. Lisboa, 1967, pp. 225-301 (pp. 229-232). 
nar eventuais provas do envenenamento do bispo de Évora pelo Rei, nada mais tinham achado do que «hum confessionário, e h uas disciprinas, e hum áspero celicio» ${ }^{65}$. Testemunham de inversão de papéis, sofrimento, castigo auto-infringido, mas sempre sem qualquer publicitação É uma verdadeira «corte outra», uma corte oculta, que deve assim permanecer para ter eficácia.

Às claras funcionou outra solução, a da «corte austera»: a implementação, com coerção moral e mesmo disciplina física, de um ambiente de frugalidade, penitência, meditação e, em última instância, total recusa dos prazeres da carne, à sociedade cortesã cujo senhor professava pessoalmente tais princípios. Em Portugal, o mais acabado exemplo foi o da corte do Infante D. Fernando ${ }^{66}$. Apesar de um lado contemplativo, o Infante não deixou de ser porém perfeitamente determinado nas linhas porque pautou o seu comportamento religioso, muito exigentes de resto. Assim, à opção pela virgindade aliou práticas devocionais bastante completas, e tentou alargar o seu modo de vida à corte a que presidia. Fazia confessar e comungar anualmente todos os seus dependentes em idade para tal, vigiava as conversas e actos dos seus criados, e tentava que eles se mantivessem castos enquanto serviam em sua casa, ou até certa idade. A luxúria parecia-lhe de facto o maior dos pecados, a ponto de se abster de alimentos e cheiros que o pudessem a tal induzir. Empenhou-se a fundo na criação de um espaço sagrado interno à sua própria corte, para a qual alcançou do Papa graças especiais que iam «das mais rreliquias de samctos que aa ssua sanctidade prouuer» às «moores endulgençias que poderdes auer» para a assistência a várias festividades na sua capela, passando por especificidades na administração dos sacramentos - escolha de confessores, faculdades de absolvição, número de capelães e missas quotidianas, relação privilegiada dos seus criados e comensais com os capelães da casa no que toca aos mesmos assuntos. Também do ponto de vista litúrgico o Infante planeia com minuncìa, pretendendo seguir pessoalmente $o$ costume de Salisbury e torná-lo ainda o comum da sua corte. Por fim, providencia pelas almas dos que viviam nesse local tão devoto, ao pedir a absolvição em artigo de morte de todos os seus servidores, quando morressem em sua casa.

Uma terceira modalidade deste tipo de relacionamento, a mais radical de todas porque rompia com a própria corte, era a fuga mundi dos cortesãos ${ }^{67}$. Por

65 Maria de Lurdes RosA, Exercício do poder e salvação da alma..., cit., p. 438.

66 Retomamos aqui aspectos da nossa análise da santidade fernandina feita em $A$ santidade no Portugal medieval. Narrativas e trajectos de vida, in Lusitania Sacra, 2. ${ }^{a}$ s., 13-14 (2001-2002), pp. 369-450 (p. 438 ss.).

67 Remetemos para uma análise aprofundada do tema, para Maria de Lurdes RosA, Exercício do poder e salvação da alma..., cit. 
termos tratado dela a fundo noutros locais, e já aludido aqui a alguns dos seus aspectos, recordamo-la apenas, pois é importante para a consideração deste campo cultural.

As cortes austeras, as cortes ocultas, e as fugas da corte tardo-medievais partilhavam, na verdade, de elementos religiosos de origem clerical. Existia uma tradição de ensinamentos e modelos alto-medievais sobre formas de salvação da alma em ambientes mundanos, que os Franciscanos tinham actualizado desde o início da existência do movimento, em função do grande sucesso alcançado junto das cortes régias e principescas. Porém, as modalidades de apropriação destas propostas pelos leigos caracterizaram-se por uma tal radicalidade que os próprios eclesiásticos se viram obrigados a inflectir o discurso. Nos séculos subsequentes, prossegue a reflexão sobre o tema, que evolui num sentido de acentuada crítica à radicalização e à tomada à letra de temas evangélicos e escatológicos, como as fora o caso de vários senhores, de Elzéar de Sabran e Delphine de Puimichel ${ }^{68}$ a Nuno Alvares Pereira, o Infante D. Fernando ou à Princesa Santa Joana que, embora com vários matizes, pretendiam transformar as suas cortes em locais de pureza e ascetismo extremo, que também praticavam, por vezes em grande profundidade. Assim, no século XV, a tendência parece ter sido a promoção da via mixta como modelo de conduta a promover junto dos grandes senhores do mundo. Este modelo pretendia a um tempo precaver atitudes extremas; travar as fugas às família e ao serviço régio, para ingresso em ordens religiosas, em geral as mais reformistas; e converter a tentação da fuga no que poderíamos chamar de «permanência mortificada», ou «virtuosa», sabiamente guiada pelos confessores, e directores espirituais, e ainda por esses «eremitas de corte» que são os «santos vivos» que nesta época começa a ser obrigatório ter, em corte devota que se prezasse - e que correspondiam, de algum modo, a trazer o eremitério para a corte, de modo a que os membros desta não fugissem para lá69.

Assim, a penitência mortificada, que se foi tornando padrão, revestia formas mais canónicas, ligadas aos tempos do calendário cristão, às práticas de peregrinação expiatória ou devocional, ou ainda sendo enquadrada pelos cada vez mais

68 André VAuchez, Deux lä̈s en quête de perfection: Elzéar de Sabran (11323) et Delphine de Puimichel (†1360), in Les laïcs au Moyen Âge: pratiques et expériences religieuses, Paris, 1987, pp. 83-92; e Elzéar et Delphine ou le mariage virginal in idem, pp. 211-224.

69 Gabriella ZARri, Le sante vive: Profezie di corte e devozione femminile tra ' 400 e '500, Turim, 1990. Mais tarde, com os Jesuítas, pedagogos da corte e mestres espirituais dos cortesãos, irão aparecer verdadeiros manuais de comportamento a este nível, sendo o mais paradigmático a Corte Santa, de Nicolas Caussin, traduzido e impresso em português em 1652. Zulmira C. SANTOS, Da «Corte sancta» à Corte Santíssima em Portugal, in Espiritualidade e corte..., cit., p. 205-216. 
comuns «directores espirituais». Temos testemunhos vários de tal na corte portuguesa na época em estudo. D. Fernando, Marquês de Vila Real (m. 1497), vinha por vezes servir os frades do Oratório da Ínsua, no refeitório, em exercício de penitência; ficava com frequência com eles, considerando-os seus conselheiros. O Duque D. Jaime de Bragança, por seu lado, tinha por devoção acompanhá-los nas matinas, à meia-noite. Anos mais tarde, a Duquesa de Bragança D. Joana (2. ${ }^{a}$ mulher de D. Jaime) e a enteada, D. Isabel, foram grandes devotas do capucho Fr. Francisco da Gatta, frade muito austero do Convento de Borba, que consultavam em vida e cuja túnica solicitaram depois de morto, uma vez que desejavam serem com ela enterradas ${ }^{70}$.

Espaços de devoção privada, tesouros de relíquias: privado, público, matéria espiritual

Os últimos vestígios das formas leigas de espiritualizar a matéria, em sede de corte, a que aludiremos, residem em duas práticas nem sempre perspectivadas naquele sentido. Por um lado, o estabelecimento de espaços do que tem sido visto como «devoção privada», porém existindo no interior de um espaço tão público quanto era a corte; por outro lado, a relação da corte com as relíquias, que foi forte a ponto de os «tesouros de relíquias» se contarem entre as mais prezadas expressões de religiosidade cortesã, e as negociações e aquisições das mesmas serem aspectos centrais da vida de corte. O que é mais interessante nestas duas questões, é que o seu papel social, em termos religiosos, tem sido interpretado como «privado». Ora, defendemos aqui que, ao contrário da «corte oculta» e práticas correlacionadas, as práticas em apreço ganhavam vida pela sua «privacidade pública». Se as primeiras, é certo, ganhavam prestígio quando desvendadas - como foi o caso das «descobertas» à morte de D. João II, acima referidas-, a sua eficácia dependia da prévia ocultação; as segundas, sendo teoricamente privadas, viviam na verdade de poderem ser exibidas como tal.

Ao longo do século XV, são muito numerosos, entre os cortesãos portugueses, e as elites em geral, os pedidos de altares portáteis, confessores privados, licença para celebração de missas em locares específicos, etc. O levantamento das ocorrências portuguesas nos registos das suas principais instâncias de concessão daquelas autorizações, entre 1412 e 1521, demonstra não só a importância de Lis-

70 Maria de Lurdes RosA, D. Jaime de Bragança, entre a cortina e a vidraça..., cit., p. 326. 
boa, como uma base sociológica de elite. Na corte, os primeiros pedidos surgem precisamente da parte do dos Infantes de Avis, que entre 1420 e 1436 apresentam 17 súplicas $^{71}$. No âmbito dos espaços dos palácios régios e nas casas dos cortesãos que gravitavam ao redor daqueles, existiam pequenos locais onde era possível ouvir missa em família; eram também possível fazê-lo em viagem, nas casas fora da corte, ou mesmo em campanhas militares; por fim, tornou-se permitido a escolha de um confessor privado, que não raras vezes eram o capelão da casa ${ }^{72}$. De que modo é que estas práticas indiciam do aspecto sobre as quais as estamos a apresentar? Desde logo, não é pelo lado de uma qualquer «privatização da religião» - e isso é fundamental, tal como fundamental é afastar as leituras seculares que assim o viram, começando nos teólogos católicos reformistas e nos protestantes, e continuando sem crítica até aos historiadores ${ }^{73}$. É que elas demonstram tanto o poder e a riqueza, como a capacidade de os transformar. E para tal têm que ser públicas. Os objectos das súplicas são decerto privilégio de ricos e de poderosos, que manifestam natural preferência por poder mandar celebrar missa em altares portáteis (o que pode com probabilidade corresponder à existência de capelas domésticas) e em escolherem os confessores (capelão da casa), ou seja, os tipos de súplicas mais reconduzíveis a uma religiosidade privada. Mas será que a posse de altar portátil e a escolha de confessor apontam para uma tentativa de privatização/interiorização da religião, ou antes para o enquadramento desta nos modos de vida próprios das elites, que tinham residências com capelas e pessoal religioso doméstico? Por outro lado, privado, interior, opor-se-ão assim tanto a comunitário, público? Estas oposições têm sentido em sociedades pré-modernas, em que o indivíduo foi uma realidade bem diferente da inaugurada pelo iluminismo setecentista e continuada pelos regimes liberais oitocentistas, que o erigiram em unidade fundamental da sociedade, estilhaçando outras formas de organiza-

71 Maria de Lurdes Rosa, Devoções de excepção no mundo da religiosidade comunitária? As súplicas ao Papa dos leigos portugueses, 1412-152, comunicação apresentada em «Espiritualidade e poder no Ocidente peninsular medieval. Colóquio Internacional» (IEM, CEHR, CSIC, 28-29 Abril 2011, de que não resultaram actas). O texto, actualizado, será publicado em 2017.

72 Sobre estas práticas religiosas de excepção, cfr. Kirsi SALONEN, Ludwig SCHMUGG, A Sip from the «Well of Grace». Medieval texts from the Apostolic Penitentiary, Washington DC, 2011 e Peter D. CLARKE, New evidence of noble and gentry piety in fifteenth-century England and Wales, in fournal of Medieval History, 34/1 (Março 2008), pp. 23-35.

73 Como provam, a partir da questão das orações e da atenção à missa, autores como Virginia REINBURG, Liturgy and the laity in late medieval and Reformation France, in Sixteenth century journal, 23 (1992), pp. 926-947; cfr. ainda a reflexão de fundo de Eamon DUFFY, Faith of our fathers. Reflections on catholic tradition, Londes, 2006. 
ção, nomeadamente as corporações e os estatutos de sangue e de função, pelas quais passava, precisamente, a vivência da religiosidade.

Se de algum modo se pode ver aqui uma separação, um olhar mais informado mostra, por um lado, que as capelas raramente eram fechadas à frequência pública, por vezes, até se pretendia atrair fiéis para as mesmas; por outro, que muito mais que individuais, eram práticas familiares, domésticas ${ }^{74}$. Tal, em boa parte, contribuía para o seu sucesso na corte, «casa de casas». O que seguramente indiciavam, face ao mundo exterior, tanto pelo que custavam a alcançar, como pelo modo de vida que as implicava, era uma prática de distinção social; mas este é fenómeno eminentemente público e não privado, pois visava acentuar uma diferença de estatuto e sublinhar superioridade. Algo, afinal, que estava na natureza do próprio ambiente de corte.

Esta perspectiva prolonga-se na questão das relíquias. A centralidade do culto destas, nas cortes, tem sido salientada por diversos historiadores, que relevam as funções devocionais e a vertente mais mundana de coleccionismo ${ }^{75}$. No que toca ao primeiro termo, também aqui se detectaria a ânsia de uma relação pessoal com o sagrado, mas mesclada de exibição da capacidade de a estabelecer, através da aquisição da relíquia (de facto, mesmo se recebidas como presente, estes objectos tinham um elevadíssimo preço, seja directo, seja quanto a obrigações contraídas no sistema de reciprocidade daquele tipo de dádivas). E como as relíquias vinham com grande frequência acompanhadas de indulgências para quem as venerasse, a abertura à veneração pública era uma obrigação cristã; o conjunto relíquias/ indulgências foi, de resto, largamente utilizado no Portugal coevo, como no restante Ocidente europeu, para aumentar o prestígio e a irradiação de capelas e conventos de fundação privada ${ }^{76}$.

Mas, para além disto, interessa realçar a natureza sacral das relíquias - na sua recepção, que não na teologia ortodoxa, muito mais moderada e até fortemente crítica quanto a diversos aspectos do uso das mesmas ${ }^{77}$. Ao serem expressões de vida eterna em restos de corpos mortos - que assim ultrapassavam esta própria condição - elas eram, de facto, sinais claríssimos de que era possível transformar

74 Ver diversos exemplos em Maria de Lurdes Rosa, As almas herdeiras..., cit., p. 669.

75 Diogo Ramada CurTo, Cultura política no tempo dos filipes (1580-1649), Lisboa, 2011, pp. 95 ss.

76 Maria de Lurdes Rosa, Sagrado, devoções e religiosidade..., cit., p. 389.

77 Dominique JulIA, L'Église post-tridentine et les reliques. Tradition, controverse et critique (XVIe-XVIIIe siècle), in Ph. BOUTRY, P. A. FABRE, D. JULIA (eds.), Reliques modernes. Cultes et usages des corps saints des Réformes aux révolutions, Paris, 2009, vol. 1, pp. 69-120; Françoise BIOTTI-MACHE, Aperçu sur les reliques chrétiennes, in Études sur la mort, 1/2007 (n 131), pp. 115-132. 
o material em espiritual. Reside aqui, quanto a nós, o enorme fascínio que exerceram no mundo cortesão. Prolongamento no mundo real dos santos, «mortos muito especiais» porque tinham realizado aquela operação com sucesso, as relíquias tinham uma fortíssima componente securitária. Por acréscimo, a metáfora do Além como «corte celestial», fazia com que a presença destes cortesãos etéreos, através de pedaços do corpo que tinham tido na vida terrena, fosse uma representação daquela na corte terrestre ${ }^{78}$. A organização das relíquias não evidentemente deixada ao acaso, pois a já poderosa mensagem de cada relíquia era ainda mais potenciada pela sua inserção num conjunto significativo. A disposição das grandes colecções que eram colocadas em relicários, retábulos, e outras formas expositivas, bem como os textos descritivos de relíquias, que vieram a constituir uma literatura específica, incluiu com frequência estatutos cortesãos, a par ou em simultâneo com as categorias eclesiásticas oficiais (mártires, confessores, virgens, etc) ou as especializações taumatúrgicas ou territoriais ${ }^{79}$.

A dádiva constrangida e o seu retorno

Embora deixada para o fim, a forma como se revestiu a circulação da caridade na corte não é o menos interessante aspecto do nosso tema. Se tudo impelia, no sistema da Cristandade, ao acto de doar, dele beneficiando - em especial quando se era rico - um microcosmos com as características da corte era especialmente propício a tal, pelas razões em que temos vindo a insistir. O que procuraremos demonstrar é que na corte este acto adquiriu contornos particulares: foi feito maioritariamente em benefício de movimentos de reforma da Igreja, em especial dos ramos observantes das ordens religiosas; foi feito seguindo sugestões (ou pelo menos imitando as tendências) régias; funcionou como uma forma de consolidar os laços cortesãos - da parte do Rei, testar a fidelidade dos súbditos; da parte destes, alcançar a benevolência e o favor régio.

Ao propor este modelo, afastamos desde logo duas suspeições: a da falta de sinceridade, na adesão aos ideais reformistas, por parte de todos os envolvidos; e a de um cru jogo de poderes e interesses, por detrás das dádivas. Antes, é preciso

78 Guy LAzure, Posséder le sacré. Monarchie et identité dans la collection de reliques de Philippe II à l'Escorial, in Reliques modernes..., cit., pp. 371-404.

79 Nicolas BOCK, Reliques et reliquaires, entre matérialité et culture visuelle, Perspective [En ligne], 2 | 2010. Uma análise de fundo sobre o desenvolvimento do culto em Edina BOZOKY, La Politique des reliques, de Constantin à Saint Louis, Paris, 2006. 
ter em conta que, por um lado, o sistema existia para anular a imperfeição dos motivos materiais por detrás dos actos de generosidade e que, por outro, o bom emprego da riqueza contribuía para prestigiar ainda mais a sua detenção. Esta é uma sociedade de conciliação de contrários e, em especial por parte dos leigos, de negociação entre instâncias e valores. Por fim, a capacidade de sedução dos ideais reformistas era porventura maior entre os ricos, poderosos e mais cultos - em boa parte pelas vicissitudes do Papado, as críticas ao laxismo eclesiástico tornaram-se fortíssimas ao longo da centúria de Quatrocentos, prolongando tendências dos dois séculos anteriores e inscrevendo-se, mais difusamente, no traço de longa duração que era a ideia da «pureza inicial», dos tempos evangélicos; e estavam presentes ainda outros traços culturais, como a sedução pelo abandono e despojamento.

Cumpre finalmente referir que estes gestos não devem ser totalmente separados de outros mecanismos de natureza mecenática, igualmente «gratuitos», existentes no seio da corte: custeio de missões diplomáticas pelos próprios embaixadores, pagamento de banquete a convidados do rei, patrocínio de criações artísticas e lúdicas, promoção de edições de livros edificantes, etc. Haverá de resto coincidência entre os praticantes desde gestos e os mecenas religiosos, sendo exemplar o caso de Fernão Lourenço, rico cortesão e feitor de D. Manuel, à cuja custa se realizaram vários banquetes do maior fausto, para receber convidados régios $^{80}$.

Durante todo o século XV, verificou-se no reino de Portugal um intenso apoio das corte e das elites aos movimentos da observância religiosa ${ }^{81}$. No virar da centúria, o processo atinge um clímax na corte manuelina, verdadeiro sistema especializado de relações entre o rei e os cortesãos, onde o primeiro, por acréscimo, assumira desde a ascensão ao trono, um élan reformador aureolado de providencialismo. As «reformas» de D. Manuel foram múltiplas, não se limitando à esfera eclesiástica e religiosa; nesta, porém, é particularmente nítido o mecanismo de recorrer aos cortesãos para a efectivar - em especial aqueles que a ele estavam ligados desde o tempo do ducado de Beja, e/ ou que eram «recémchegados» aos altos círculos da corte. A efectivação deste recurso fazia-se de diferentes modos, mas um dos mais eficazes e correntes, foi a sugestão de fundação de

80 Maria de Lurdes Rosa, Além da aventura, aquém do capitalismo?: elementos para a bistória de Fernão Lourenço (1481-1505), um «perito económico» na Expansão portuguesa, in Lisboa medieval. Os rostos da cidade, Luís KRUs, Luís Filipe OLIVEIRA, João Luís FONTES (coords.), Lisboa, 2007, pp. 335 367.

81 Maria de Lurdes RosA, D. Jaime de Bragança..., cit., pp. 325-26. 
capelas fúnebres, ou a instituição de outros sufrágios mais simples, em mosteiros protegidos pela Coroa, auxiliando a construção ou renovação dos mesmos. Entre outros casos, podemos ver cortesãos muito próximos do rei (e ao serviço ducal e régio devendo a sua ascensão), como Álvaro da Costa, a fundar uma capela fúnebre na Penhalonga, mosteiro jerónimo de especial predilecção régia, e a proteger a reforma dominicana, nomeadamente em conventos femininos; a capela da Penhalonga é colocada sob invocação de Nossa Senhora da Piedade, invocação paralela à da «Senhora da Misericórdia», tão prezada por D. Manuel e pela sua régia irmã; no documento de fundação D. Álvaro refere que o local que lhe fora «dado» pelo Monarca; além dos sufrágios pelas almas do fundador e seus finados, manda celebrar outros por alma d'O Venturoso; por fim, faz expressamente registar, no contrato com os frades, que assim manda sufragar aquele «de quem elle dicto Aluaro da Costa diz teer Reçebido toda homrra e merçe que tem depoois de deus ${ }^{82}$. Outros casos afins são os de Vasco Eanes Corte-Real e D. João de Meneses em São Francisco de Lisboa ${ }^{83}$ - com indicação expressa do gosto régio por tal - ou o já referido riquíssimo feitor da Casa da Índia, Fernão Lourenço, a aproximar gradualmente o seu mecenato às ordens religiosas protegidas pelo rei e pela sua irmã, a Rainha viúva D. Leonor ${ }^{84}$.

De facto, este tipo de gestos tinha uma tradição anterior, algo diversa. Pelo menos desde meados do século XIV, que os «protegidos» régios (numa acepção lata) de determinado perfil incluíam, nos sufrágios a manter nas suas capelas, o(s) rei(s) que os tinham favorecido, bem como as respectivas famílias ${ }^{85}$. Há aqui uma espécie de reciprocidade, na permissão para exibir uma familiaridade espiritual com os mais importantes senhores do Reino - talvez, mesmo, uma capacidade de «dar» aos reis e príncipes, a troco do financiamento de projectos religiosos por estes alimentados. A protecção régia às ordens religiosas observantes e reformistas, que se fez muitas vezes ao arrepio dos principais poderes eclesiásticos do Reino, bem como o grande aumento da complexidade da figura redistributiva do Rei, ampliou esta tradição até ao sistema do custeamento dos apoios, tal como o caracterizámos acima. Para comprovar a extensão desta prática, seria preciso le-

82 Retomamos aqui, parcialmente, o nosso estudo da religiosidade de Álvaro da Costa, A religiosidade de Álvaro da Costa. Devoção, reformismo e distinção social, in Maria Lurdes RosA (dir.), D. Alvaro da Costa e a sua descendência, sécs. XV-XVII: poder, arte e devoção, Lisboa, 2013, pp. 209-246.

83 Maria de Lurdes RosA, As almas herdeiras..., pp. 267, 282-83, 361-362.

84 Maria de Lurdes Rosa, Além da aventura, aquém do capitalismo?, cit.

85 Maria de Lurdes Rosa, A religião no século..., cit., pp. 460 ss.; Maria Amélia CAMPOS, The bequest of Pedro Domingues, 1335: the foundation of a chapel in honour of Dona Branca, princess of Portugal, in the church of Santa Fusta of Coimbra, in Medievalista [Em linha]. No 20 (Julho-Dezembro 2016). 
var a cabo uma investigação aprofundada sobre as capelas fundadas no séculos XV e XVI nos conventos observantes de Lisboa e arredores, bem como das dádivas mais genéricas aos mesmos. Não sendo possível aqui fazer tal tarefa, mencionaremos, para terminar, a segunda grande prova da proactividade dos cortesãos leigos (incluindo, claro, o rei D. Manuel e as adjuvantes essenciais que foram a irmã Leonor, a mãe Beatriz, e a mulher Maria) no processo em estudo: a criação das confrarias das Misericórdias.

Este acontecimento foi absolutamente central na religiosidade da corte do período em apreço, e é de facto um perfeito exemplo da capacidade dos leigos em assumir a direcção no processo de espiritualização da matéria e da riqueza. De controle quase exclusivamente leigo, as Misericórdias abrangiam, além disso, um vastíssimo leque de acção caritativa, sob a denominação das «obras de misericórdia» e criaram também uma tipologia de «bons pobres», isto é, aqueles que mereciam ser auxiliados (os que possibilitavam e beneficiavam da «conversão da riqueza»); realizavam vastas acções cerimoniais, que marcaram todo o espaço religioso de Portugal e do seu Império, a partir de então (com destaque para as procissões da Semana Santa. Propuseram, por fim, um programa de espiritualidade e devoção aos seus membros, em especial aos que faziam parte dos corpos dirigentes, ou «Mesa». Em Lisboa, a Misericórdia tinha uma fortíssima ligação ao Rei e, claro, à sua irmã D. Leonor, a grande implementadora do movimento ${ }^{86}$. Entre os muitos aspectos relevantes das Misericórdias, para o tema em apreço, estes dois últimos são particularmente fortes. Veremos tal regressando ao caso de D. Álvaro da Costa, que desempenhou um papel de grande relevo na Santa Casa de Lisboa ${ }^{87}$. Os capítulos que acrescentou ao «Regimento» primitivo, de 1516, aquando do desempenho do cargo de Provedor em 1539, são elucidativos.

Quanto à espiritualidade dos membros da Mesa, um primeiro conjunto de preceitos dizia respeito ao que poderíamos chamar de purificação ritual e de consciência, prévia ao desempenho de cargos com responsabilidade de gestão de dinheiros «sacralizados» ${ }^{88}$. Estatuem o provedor e os irmãos que, antes de distribuírem as esmolas, devem purificar-se e preparar-se, de modo a que apenas

86 Isabel Gutmarẽes SÁ, As Misericórdias portuguesas de D. Manuel I a Pombal, Lisboa, 2001.

87 Para além do seu papel de constante conselheiro de D. Manuel, pode ter desempenhado o cargo de primeiro provedor da Misericórdia de Lisboa; e terá aconselhado o Rei na implementação da política de dotes a donzelas órfãs, depois da morte da Rainha D. Maria (cfr. Maria de Lurdes RosA, A religiosidade de Álvaro da Costa..., cit., pp. 235 ss.).

88 Retomamos aqui aspectos do nosso estudo, A religiosidade de Álvaro da Costa..., cit.. A religiosidade do cortesão incluía ainda outros elementos de afinidade com a acção régia, nomeadamente a concessão de dotes a donzelas órfãs. 
a força da graça divina presida a esse exercício. Exercício de poder, como bem se entende, mas poder que tem que ser subordinado à moral e à obrigação para com as almas. As obras adquirem valor se realizadas com o coração puro que a frequência dos sacramentos da confissão e da comunhão conferem: o provedor e os irmãos passam a ter que cumprir um programa espiritual e sacramental ancorado nas datas de festa dos santos e efemérides fundadoras, que forneciam a base da espiritualidade confraternal: confissão e comunhão em conjunto logo após a eleição (dia da Visitação a Santa Isabel, a 2 de Julho), na festa do Nascimento de Nossa Senhora (8 de Setembro), na festa da Imaculada Conceição (8 de Dezembro), e na Quinta-Feira Santa. O programa visa «que o senhor deos estando em estado de graça reçeba as ditas esmolas em sacrifício e se quera amercear das almas que as deixaram e aos viuos conserve e aos que as despendem bem ordenar e bem guastar e a todos leue a sua gloria» ${ }^{89}$.

Estas ideias, que não seriam seguramente apanágio apenas de Álvaro da Costa, mas que eram sem dúvida por ele comungadas e preconizadas, pode proporcionar-nos uma interessante síntese sobre a actuação do homem político-religioso: se o poder e a riqueza existem, a sua posse tem responsabilidades morais, e é preciso exercê-lo de forma recta; por outro lado, a caridade deve ser eficaz, a riqueza deve ser «bem gasta», e daí a sua gestão por um conjunto de pessoas preparadas. D. Álvaro da Costa e os irmãos da Mesa andavam aqui perto das concepções paternalistas do poder político, que o imbuíam de uma sacralidade específica, dando-lhe direito a estender o múnus governativo às «almas dos súbditos», e que tinham constituído o cerne da actuação dos reis da dinastia de Avis, alcançando brilhantíssimo cume com D. Manuel e a sua irmã D. Leonor, precisamente na relação com a redistribuição de bens sacralizados aos súbditos mais pobres e indefesos.

O segundo conjunto de capítulos adicionados ao Regimento nesta provedoria de Álvaro da Costa tem como objectivo o reforço da ligação à monarquia e à corte exemplar que promovera a criação destas confrarias. Prolonga a prãtica acima descrita, de acrescentar sufrãgios pelas almas da familia régia, nas capelas de alguns cortesãos (como fizera o própio D. Álvaro da Costa na sua fundação). Está presente mesma comunhão de mortos, vivos, sufrágios e recompensa, a par da exemplaridade moral e do reforço «político» - no sentido lato - da confraria da Misericórdia, vista como projecto querido de uma Monarquia caritativa e bene-

89 Capitulos do Regimento de 1539 presentes no Regimento da Misericórdia de Évora, ed. in Documentos Históricos da Cidade de Évora, ed. Gabriel PEREIRA, Évora, 1887, 2. a p., p. 142. 
ficente. Neles é a consignada a obrigatoriedade de celebração solene da memória dos fundadores da Misericórdia de Lisboa - o casal régio D. Manuel e D. Maria, a Rainha D. Leonor de Aragão e a Rainha D. Leonor de Habsburgo. D. Álvaro torna obrigatórias, acrescentando-as ao Regimento original, várias cerimónias de sufragação das almas daqueles régios personagens, bem como de encomendação da prosperidade do rei D. João III e da família real. Todas elas se desenrolavam segundo formalismos solenes, com pormenores cerimoniais de forte significado e impacto, como o grande número de velas acesas e a disposição dos irmãos em redor da tumba onde eram ditas as orações, e o desenrolar dos sufrágios pela véspera e pelo dia de cada efeméride. 